\title{
An Analysis of the Megatrends Effects on the Future of the Iranian-Islamic City through Structural Analysis and Scenario Planning: A Case Study of the Historical Context of Tabriz
}

\author{
Masoumeh Ayashm* \\ PhD in Islamic Urbanism, University Instructor and Urban Planner, Tabriz, Iran. \\ (Received 28 Nov 2020, Accepted 28 Jan 2021)
}

The world today is witnessing an ever-increasing number of events taking place across countries. These events, which are the driving forces of globalization, are progressing and transforming cities at all levels, and levels as megatrends and trends. As a result, new needs and issues are emerging in cities that take cities away from their core values. The cities of Iran are no exception to this rule and have been affected by these megatrends and trends. The megatrend refers to a phenomenon that, given its previous developments, can be seen to have a certain direction and can be expected to move in the same direction in the future. The megatrend refers to regularities that consist of a combination of several smaller sub-trends. Therefore, the most important characteristic of the megatrend is its high importance, high probability and its continuity over time. Therefore, the main purpose of this article is to understand the effects of current megatrends and trends on the Iranian-Islamic city and future of that, with a structural analysis and scenario planning approach. The main question of the research is: What is the future of the Iranian-Islamic city in the face of megatrends? And what are the trends in the contemporary Iranian city and the trends in the historical context of the city of Tabriz? The research method is a complex combination, using library and documentary study, Delphi technique (questionnaire, in-depth interview), structural analysis technique, and scenario writing. The first step in future research is to discover the trends that are currently underway. So, according to the studies and surveys conducted, 21 trends in contemporary Iranian cities were identified. Then, the 12 trends of Tabriz city were explained and using the technique of structural analysis and scenario planning, the future of the Iranian-Islamic city in the face of the trends of Tabriz city in the form of triple urban scenarios (optimistic and golden scenario, pessimistic and catastrophic scenario and continuation scenario) were analyzed. One of the important results of the present dissertation is the orientation of the third scenario towards the second scenario, which re-emphasizes the need for a serious review of the policies of the historical context of the Tabriz city. Among the twelve trends in the historical context of Tabriz, the trend of virtual communication, the trend of urban issues, the trend of consumerism, the trend of machine life and the trend of apartment living have the most tendency towards the pessimistic scenario. This indicates the need for special attention and recognition in the policies of organs and institutions related to these trends. Ignoring the trends and their effects on the city and its values and insisting on current processes in the city structure cause irreparable damage to cities. Therefore, it is necessary to have a conscious view of trends and their initial identification. This can create many grounds for changes in urban management systems and other urban layers and being the initial basis for the same great movement in Iranian-Islamic valuable cities.

Keywords: Mega-Trends, Future of Iranian-Islamic City, Structural Analysis, Scenario Planning.

\footnotetext{
${ }^{*}$ Corresponding author. E-mail: masoumeh.ayashm1389@gmail.com

Copyright (2) 2020, the Authors / This open-access article is published under the terms of the Creative Commons AttributionNonCommercial 4.0 International License which permits Share (copy and redistribute the material in any medium or format) and Adapt (remix, transform, and build upon the material) under the Attribution-NonCommercial terms.
} 


\section{واكاوى تأثيرات كلانروندها بر آينده شهر ايرانى -اسلامى با

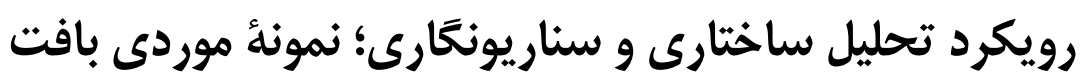 تاريخى تبريز}

\section{معصومه آيشم"}

دكترى شهرسازى اسلامى، مدرس دانشكاه و يروهشكر آزاد، تبريز ، ايران.

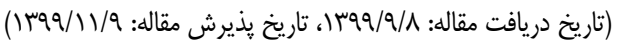

جهان امروزه شاهد افزايش روزافزون رويدادهايى هست كه در سرتاسر كشورها جريان مىيابند. بهتبع اين موضوع،

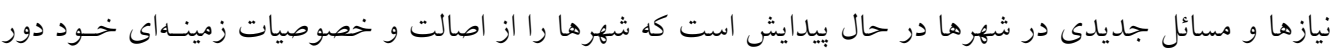

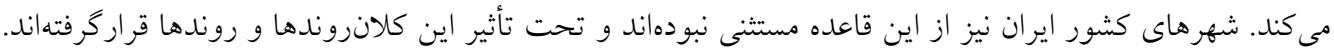

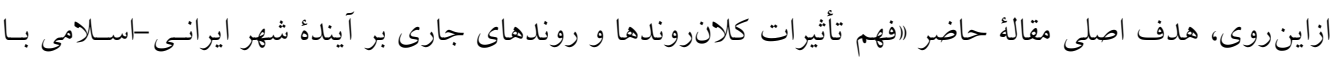

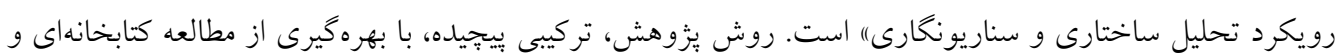

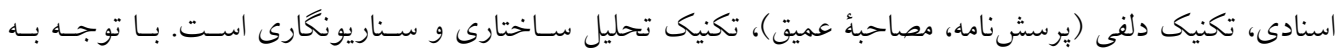

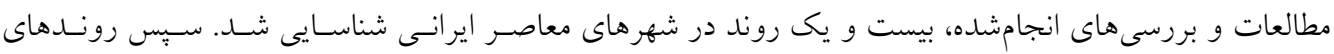

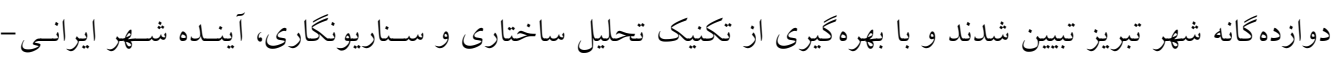

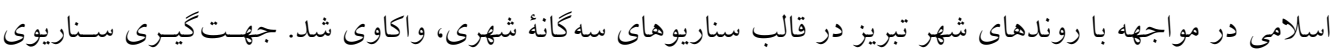

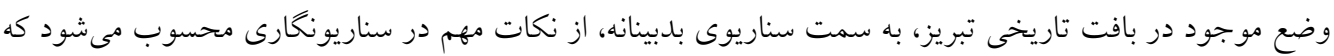

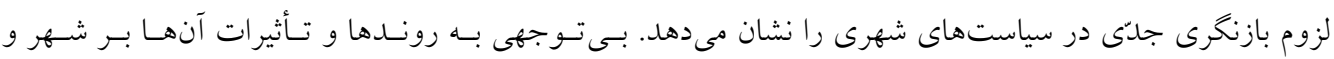

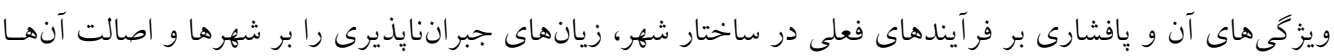

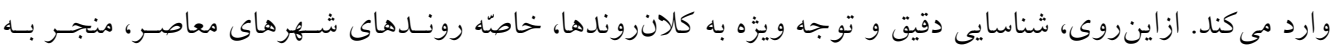

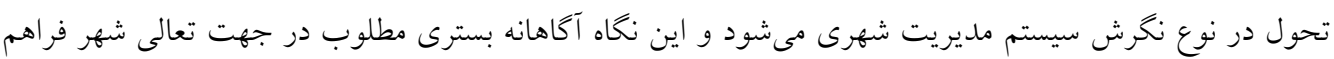


روندهاى جارى بر آينده شهـر ايرانسى-اسـلامى، بـا رويكــد

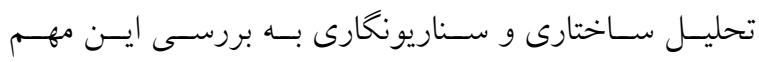

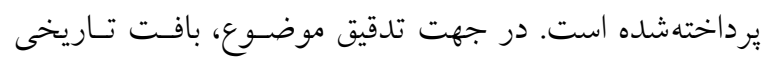

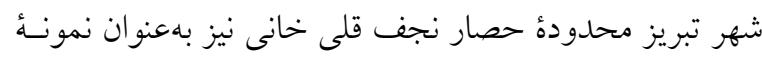

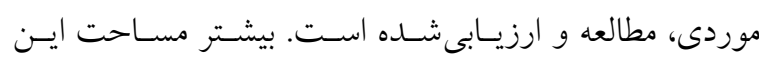

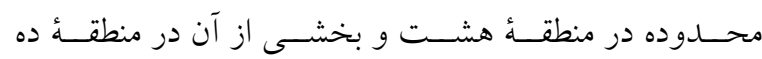

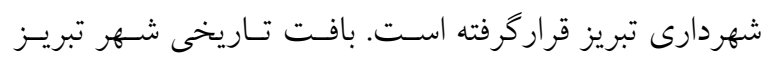
بهنوان يكى از بافتهاى بيوستؤ تاريخى كشور ايران، امـروز در معرض جالشهاى بسيارى است كه اين جـالشهـا منجـر

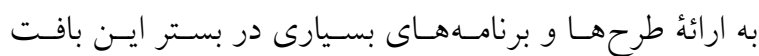

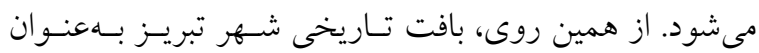

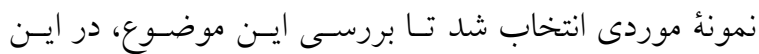

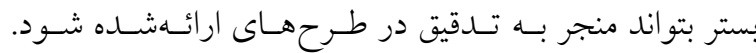

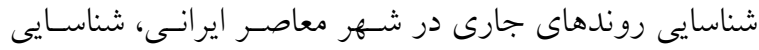

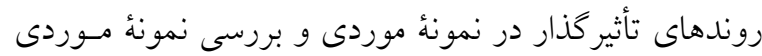
با استفاده از تكنيك سناريو نخارى و تحليل ساختارى ازجمله عناوين كليدى در مقاله حاضر هستند كه در ادامه بـه تفضسيل

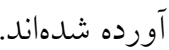

كلانروندها ارائه شده است. وازٔة كلانروند بـــاى اولـين بـار

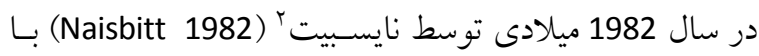

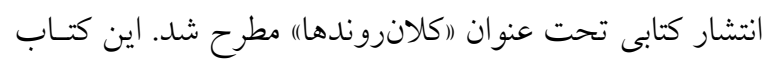

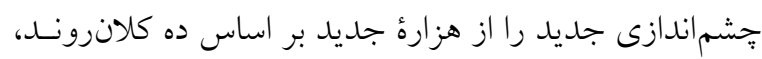

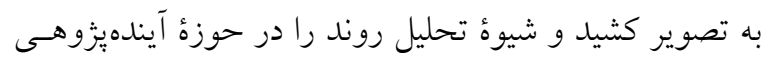

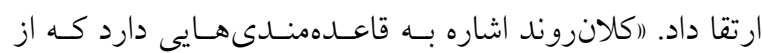
تلفيق جندين روند فرعى و كوقجكتر تشكيل شدهاند. بنابراين

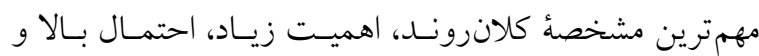

تداوم آن در طول زمان است)| (Toivonen 2004). كلانروندها ازلحاظ ماهيت، به كونهاى فضاى كسبو كار و جامعه را تغيير مىدهند كه اثرات آنهـا نـه سـالهـا، بلكـهـ

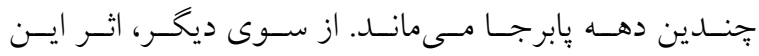
كلانروندها بر هر فرد جامعهُ انسانى خواهل بود و فرصتهـا
امروزه تغييرات جوامع با سرعت بيشترى به وقوع مى بيوندند.

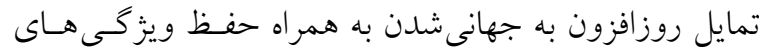

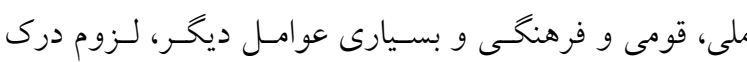

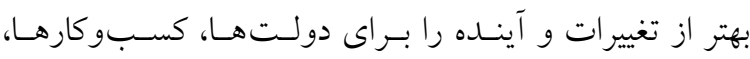

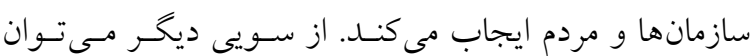
شاهد افزايش روزافزون رويدادهايى بود كه در سرتاسر جهان

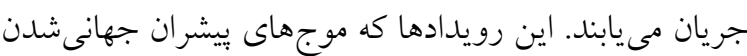

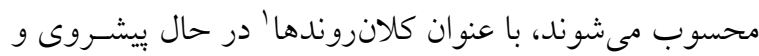

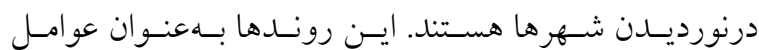

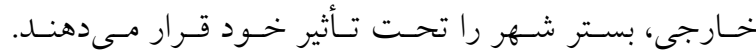

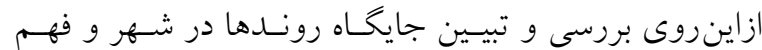

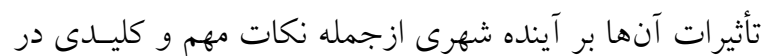

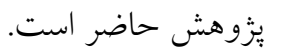

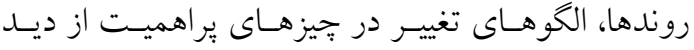

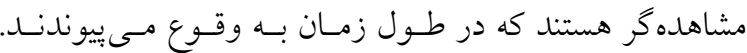
نخستين كام در آينـدهيزوهـى، كشـف رونــدهايى اسـت كـهـ هماكنون در جريان هستند (Moqimi 2015). در همين راستا

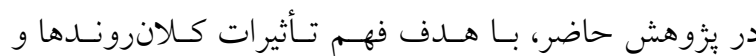

\section{| ا. جهار קوب و مبانى نظرى يزوهش

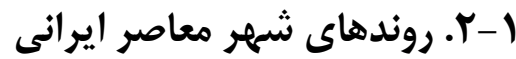

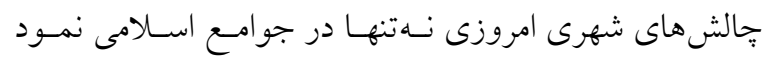

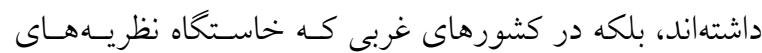
شهرى محسوب مىشوند نيز ايجاد شدهاند. توسعـة نـامتوازن

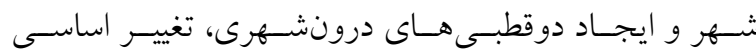

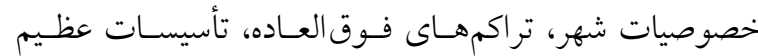
زيربنايى و سرمايهــــارىهــاى بسـيار گســرده از ايـن قبيـل هستـند (Pirbabaei 2018). يكسى از محوريـتهــاى مهـم در بحث مطالعهُ آيندة شهرها و ارزيابى كيفيـات جشـــانــازهاى

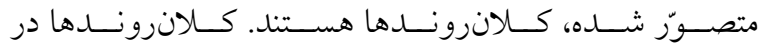
يَزوهشهاى امروزى بخـش اساسى را بـه خـود اختصـاص

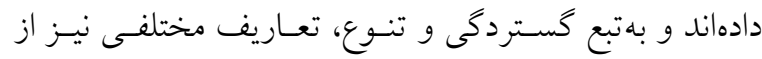


واكاوى تأثيرات كلانروندها بر آيندة شهر ايرانى-اسلامى با رويكرد تحليل ساختارى و سناريونكارى؛ نمونهٔ موردى بافت تاريخى تبريز

تمركزدايى؛ 7) نخرش جديد بـه فردخرايس؛ V) دموكراسى

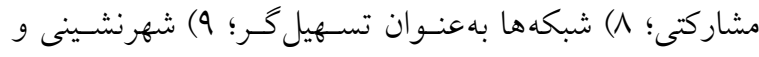

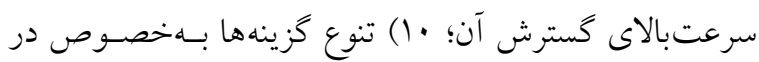
رابطه با نقش زنـان در جامعسه. مكعكان (McCann 2016)

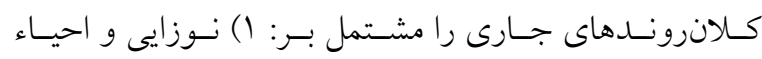

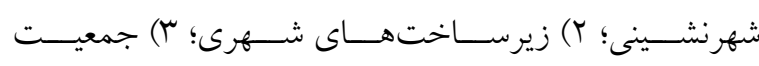

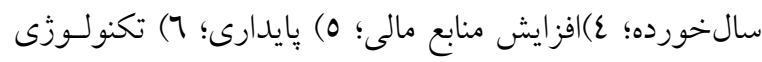

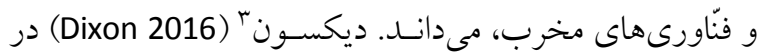

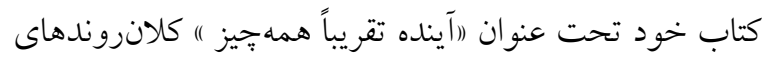

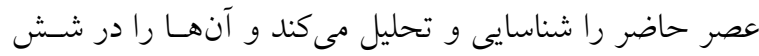

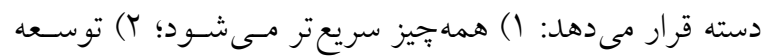

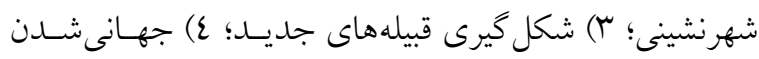

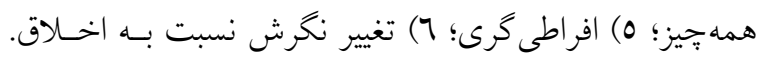

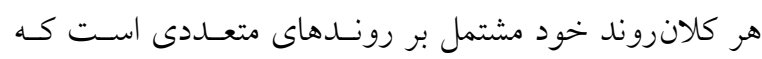

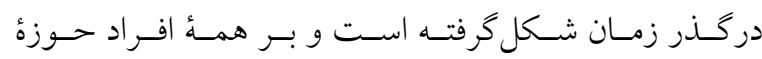

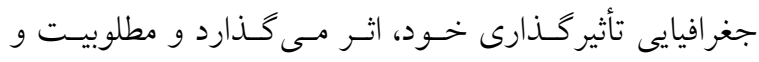
نامطلوب بودن از نتايج اين روندها و كلانروندها است.

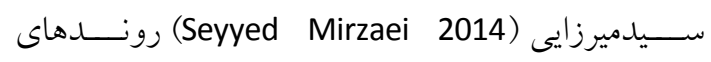

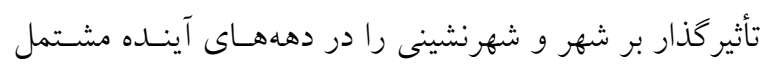

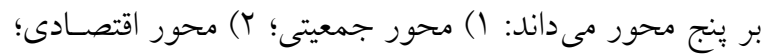
r) محسور اجتمـاعى؛ ع) محسور زيستمحيطى. دولتشــاه (Dollatshah 2016)

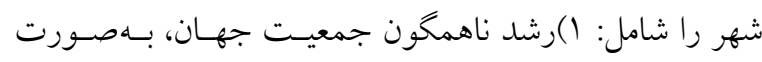

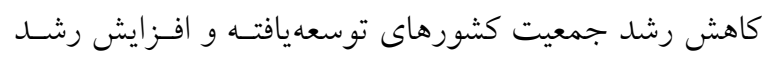

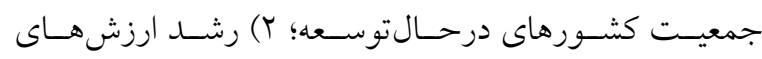

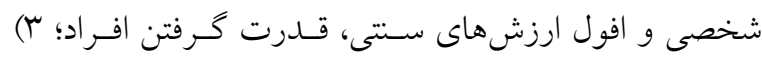

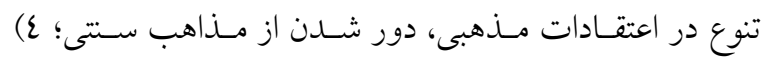

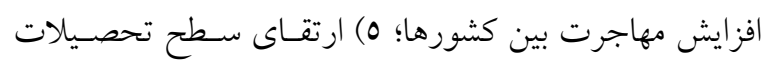

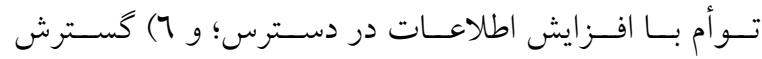

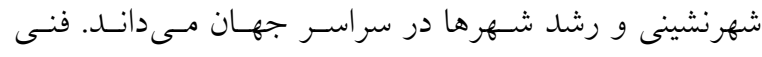

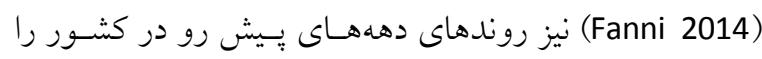

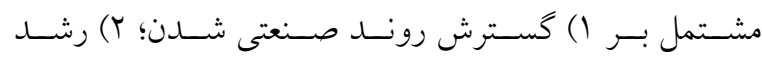

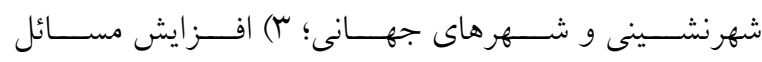
محيطزيست؛ ع) شكاف وسيع جهانى ميـان فقــ و غنـا؛ و 0) مهاجرتهاى انسانى؛ مى داند.
و تهايدات ويزٔه خـود را بـر فضـاى كسـبوكـار و جوامـع انسـانى فـرود مسى آورنــ (Schwenker and Raffel 2014).

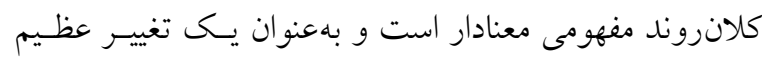

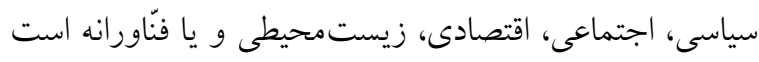

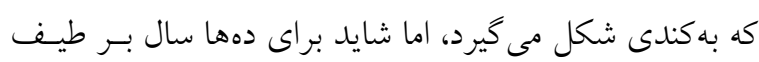

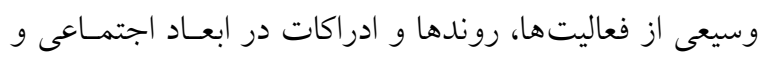

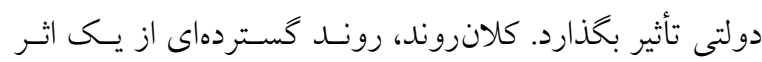
عمده و يا تركيبى از زير روندهايى است كـه خــود قـادر بـهـ خلق تأثيرات عمده هستند (Sheate and et al 2007).

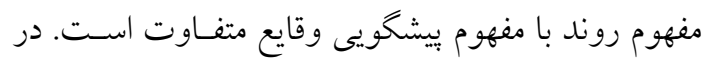

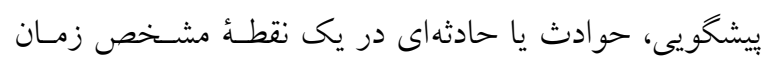

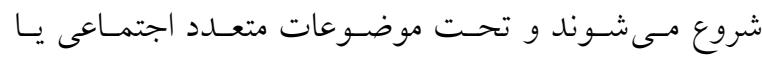

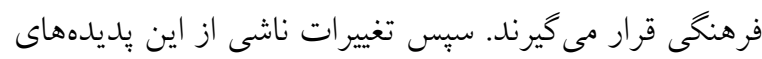

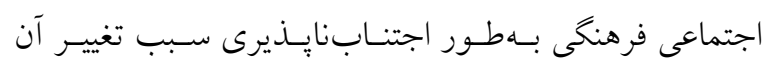

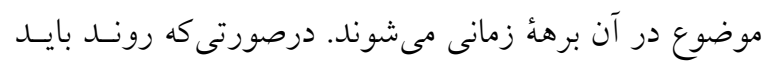

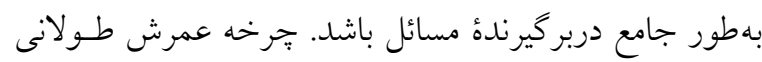

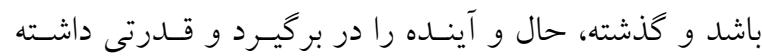

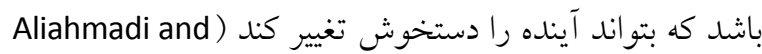

.et al 2007

ازاينروى مىتوان كفت، روند (ترند) درواقع رويداد و يا

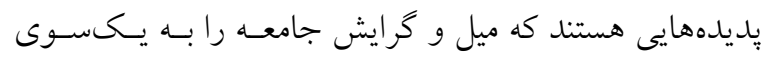

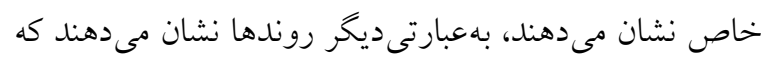

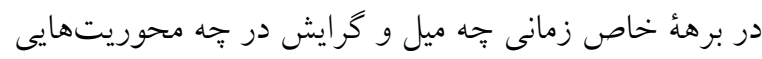

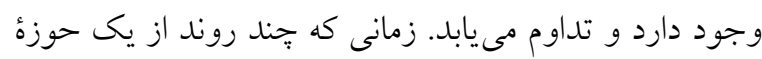

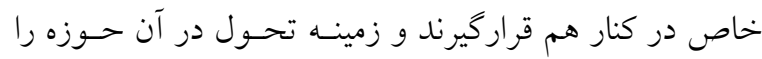

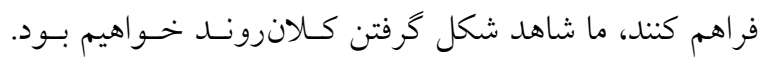

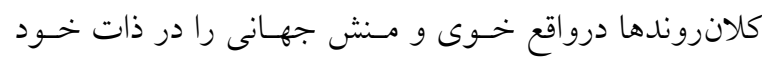

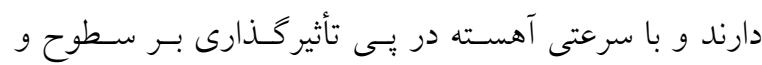
لايههاى مختلف شهر امروزى هستند.

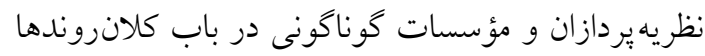

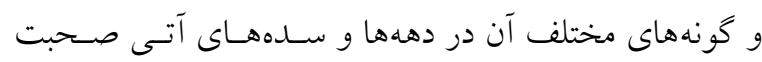

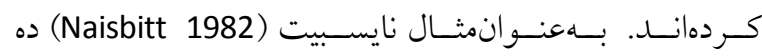

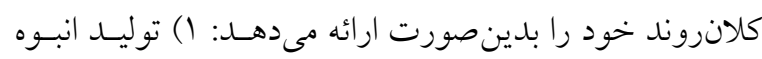

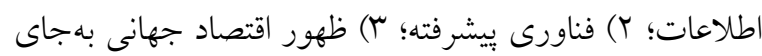

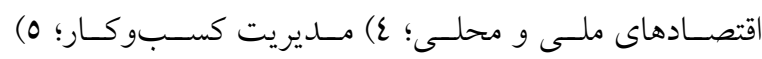


نقـــــ از متخصصــان ايسـن حــوزه ارائسه شـــــ و در تكنيـك

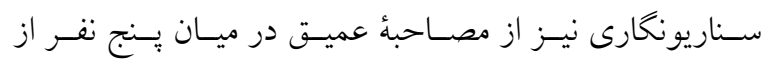

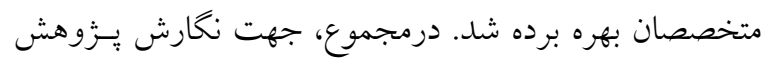

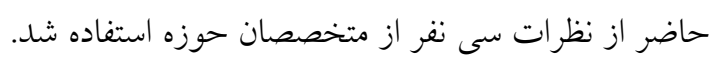

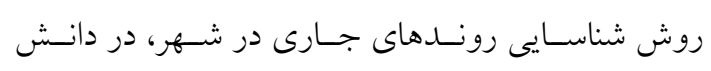

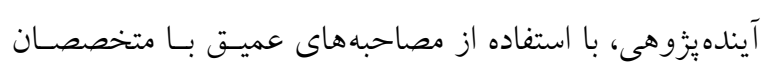

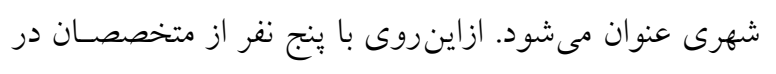

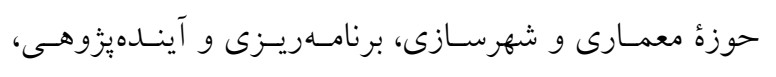

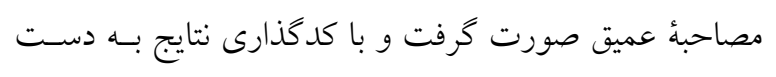

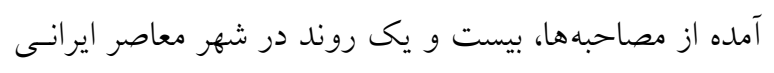

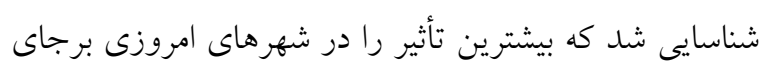

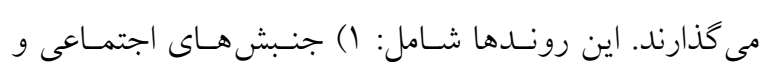

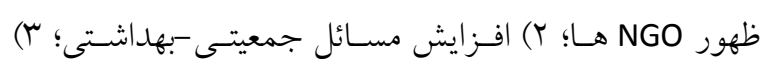

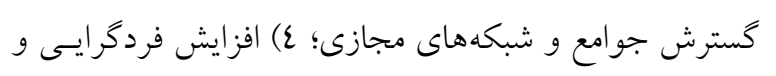

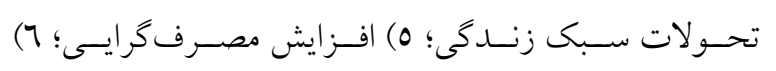

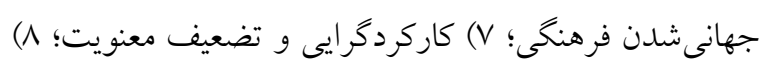

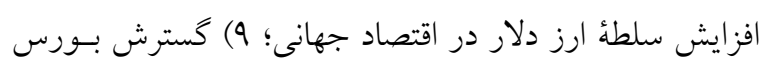

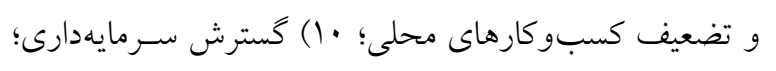

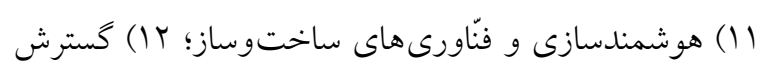

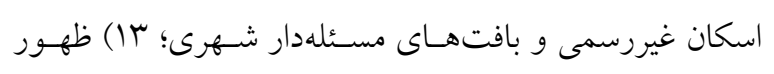

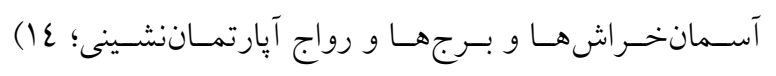

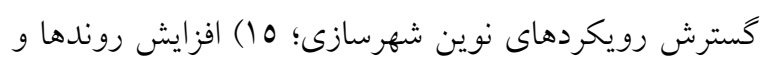
قوانين بين المللى در حوزههاى ورزشى و فرهنخ ونى و ... ؛ 17 )

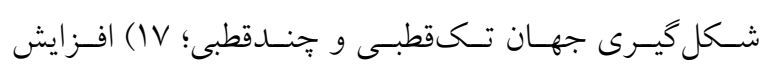

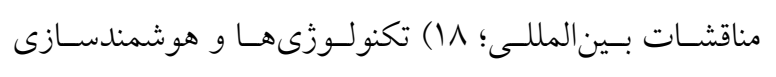

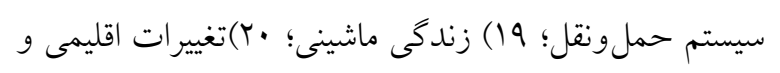
كاهش منابع حياتى و (Y) صنعتى شدن است. از سويى ديخــ

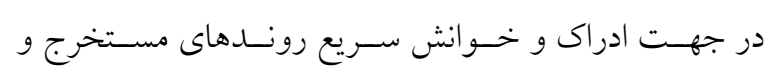

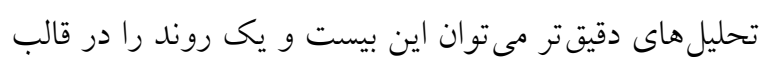

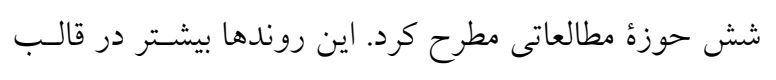

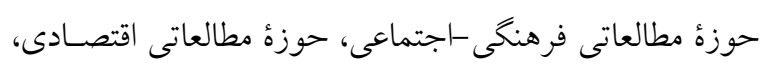

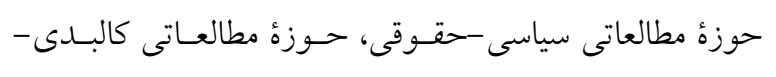

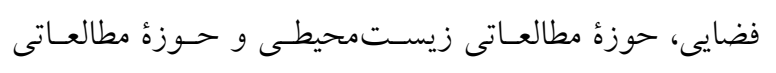
حملونقلى قرار مى گيرند.
با توجه به ديدكاههاى آورده شده در رابطهـ بـا موضـوع

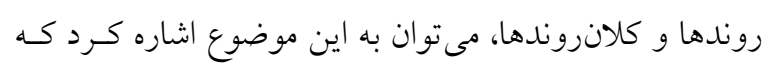
كلانروندهاى عصر حاضر، درمجموع يكسان هستـند و تنها

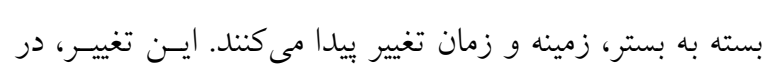

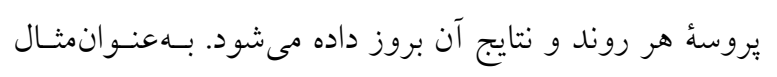

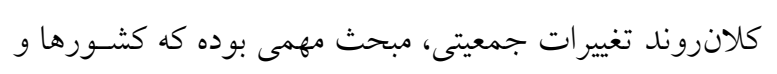

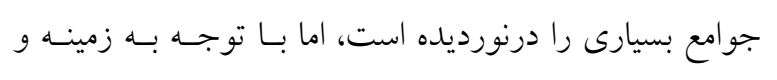

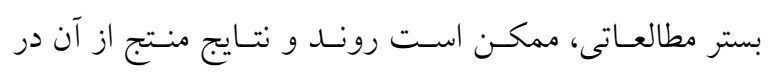

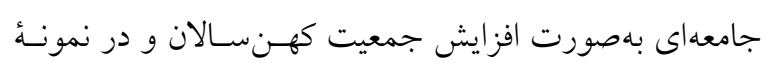

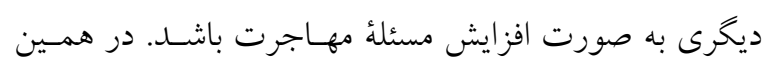

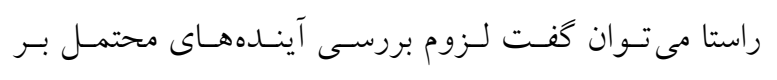

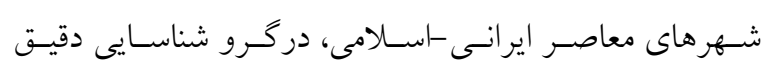

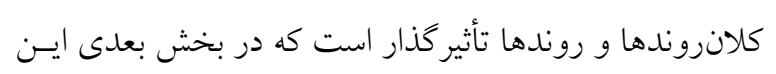
مهم، تبيين شده است.

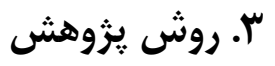

روش تحقيق درواقع، مفصلى است كه طرح نظرى تحقيـق را

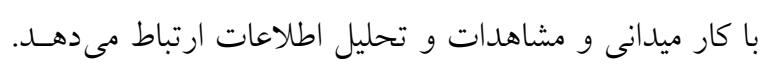

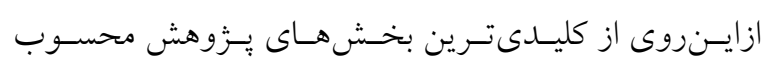

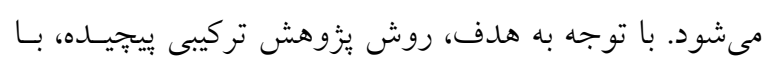

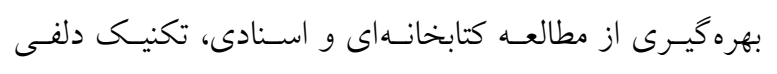

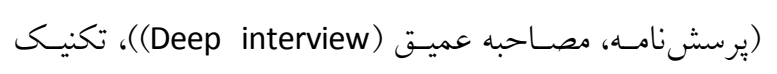
تحليل ساختارى و سناريو نغارى با نرمافزار ميك مكى است است.

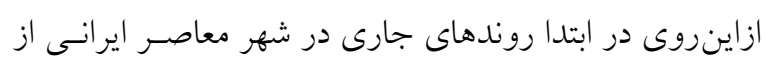

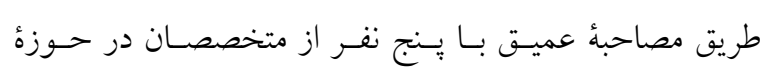

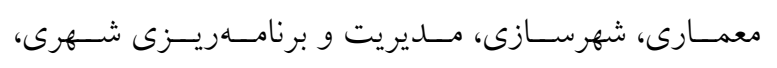

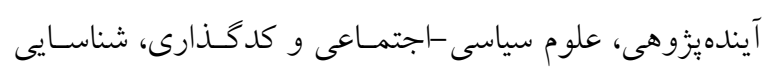

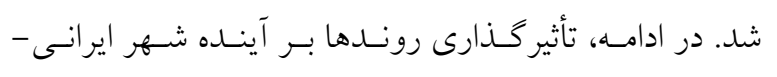
اسلامى در نمونهُ موردى (بافت تاريخى تبريز محدودة حصار

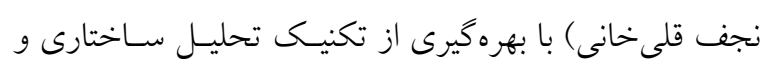

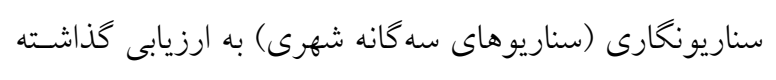

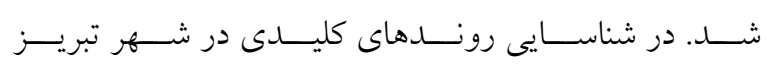

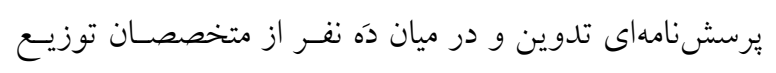
شد. در تكنيك ساختارى نيز يرسشنامـهاى مجـزا درميـان دَه 
واكاوى تأثيرات كلانروندها بر آيندة شهر ايرانى-اسلامى با رويكرد تحليل ساختارى و سناريونكارى؛ نمونأ موردى بافت تاريخى تبريز

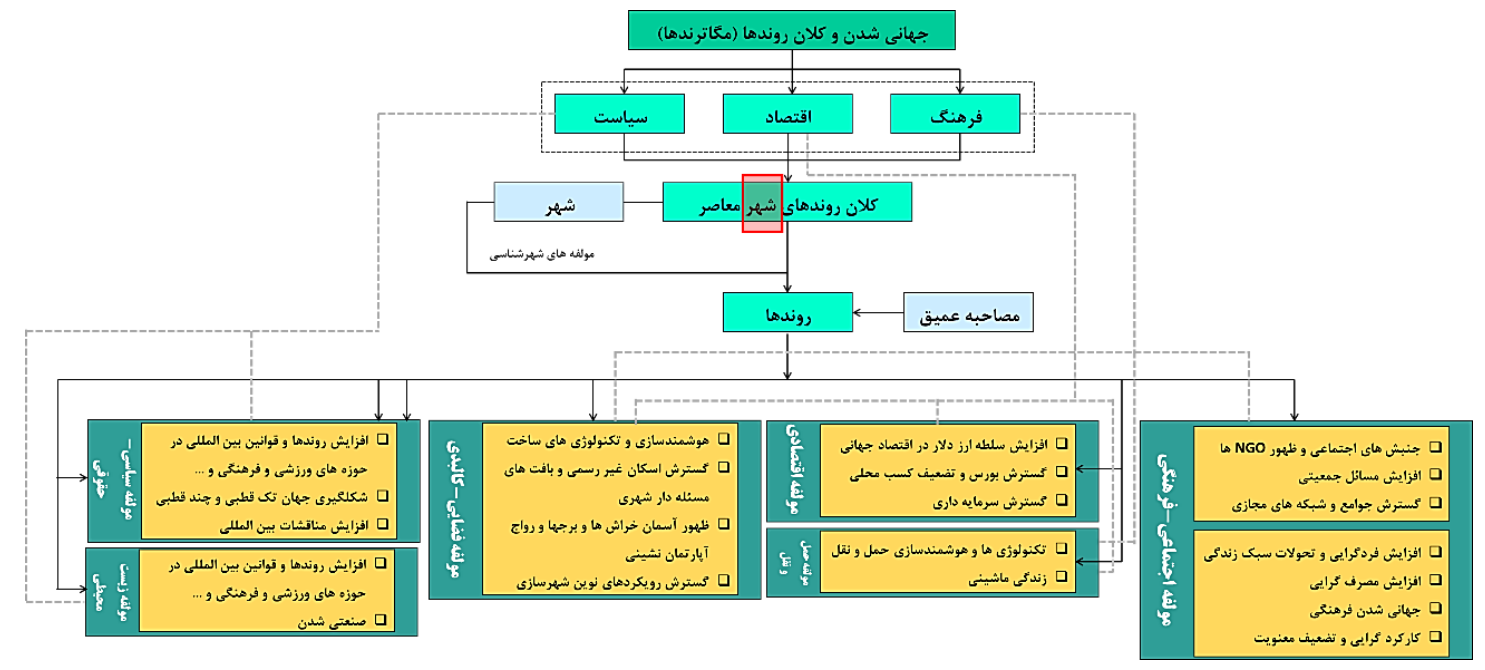

تصوير ا: شناسايى و استحصال كلانروندهاى شهر معاصر ايرانى

Fig. 1: Identifying and achieving the Megatrends of the Iranian contemporary city

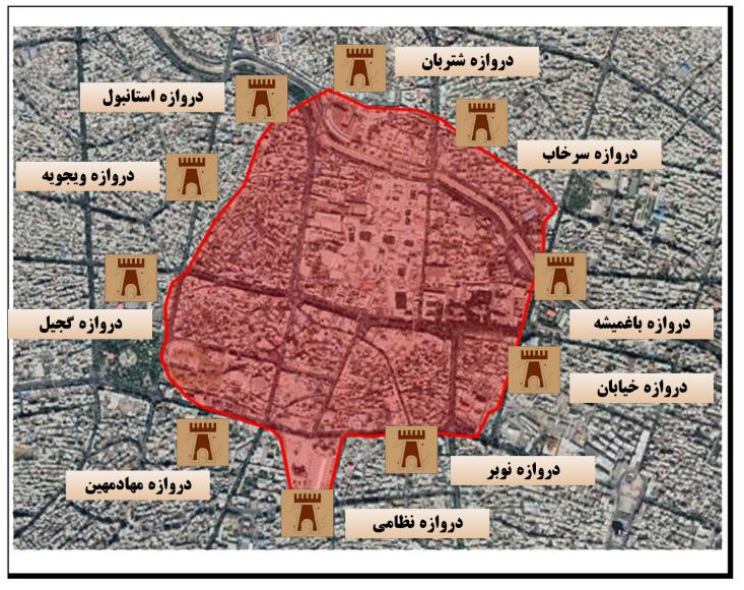

تصوير ז: موقعيت حصار و دروازهاى تاريخى آن

Fig. 2: The location of the fence and its historic gates, Source: Author

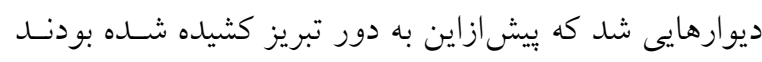

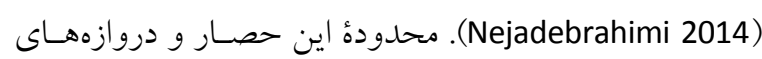
آن را مىتوان بدينصورت نشان داد.

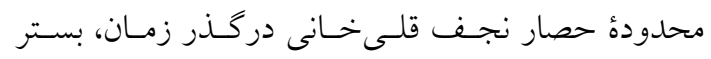

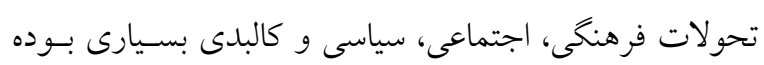

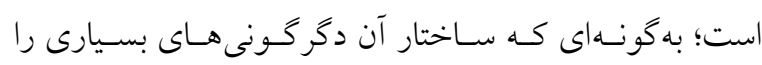

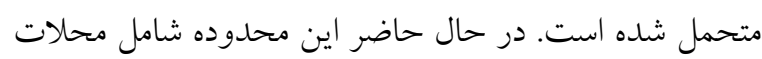

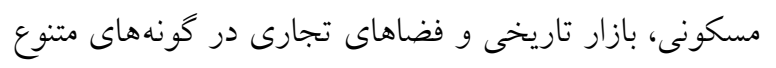

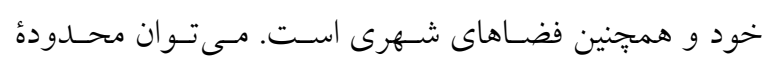

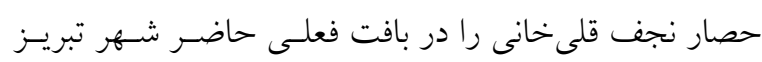

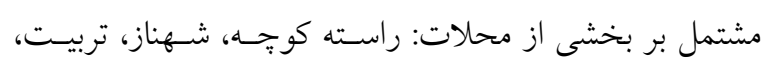

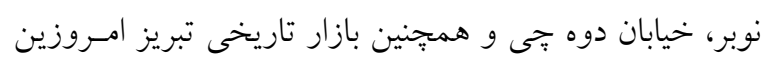

\section{ع. بحث و يافته هاى يزوهش}

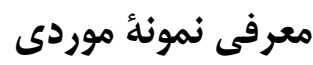

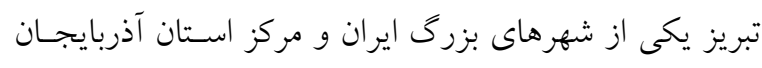

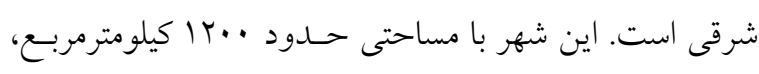

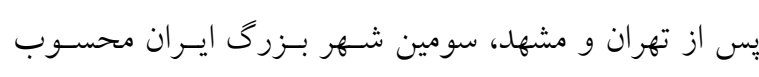

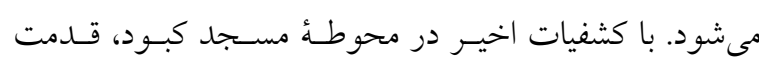

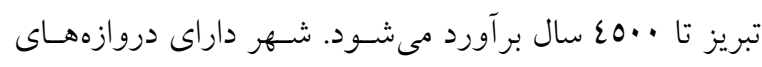

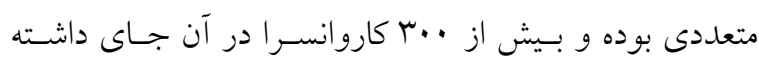

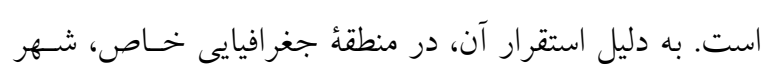

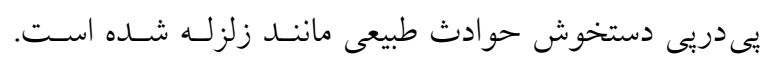

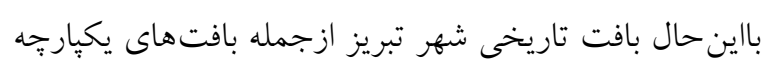

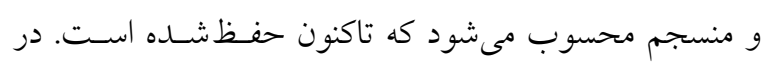

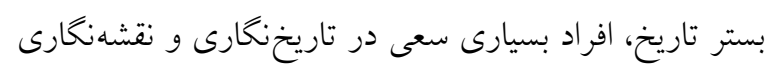

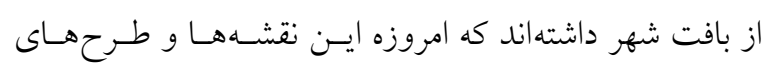
ترسيمى در شناسايى محدودة بافت تاريخى شهر تبريسز، سـير

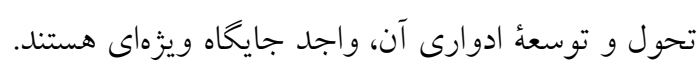

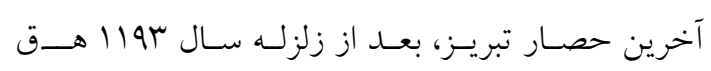

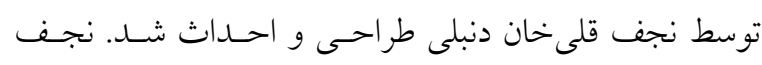

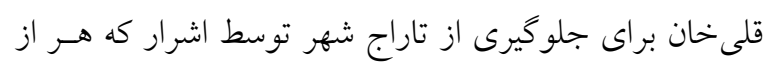

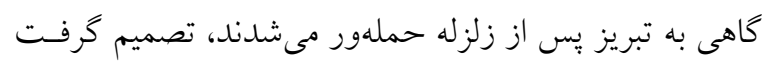

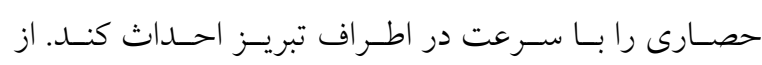

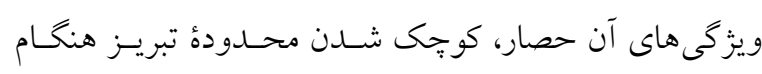

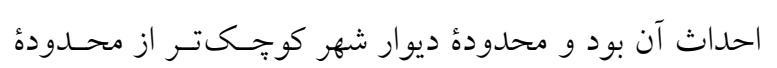




\section{سناريونكارى با تكيهبر تكنيك تحليل ساختارى}

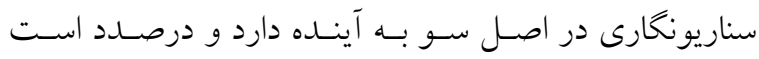
حالات اصلى مستقل و متمايز را كه از لحظةٌ شروع محسدودهُ

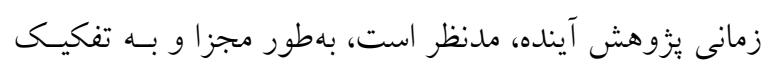
هر روند و هر يك رادر قالب يك سناريو موردبررسى قـرار دهد. اولـين گَام در تـدوين سـناريو، شناسـايى و اسـتخراج رونـدهاى جـارى در مـورد يزوهـى اسـت؛ در ايسن مرحلـه

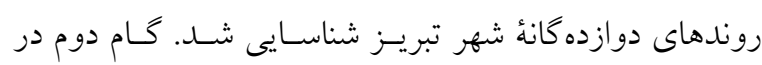

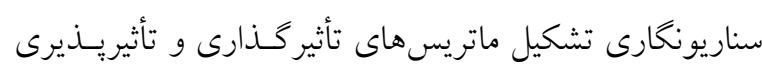

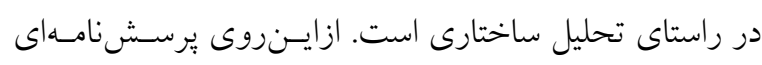

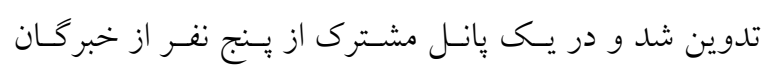

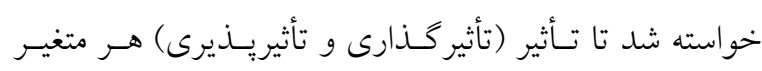
(روند) را بر متغير (روند) ديخر در طيفى از صفر تا سه (عـدد صفر به معناى نبود رابطه، عدد يكى بـه معنـاى رابطـه و تـأثير

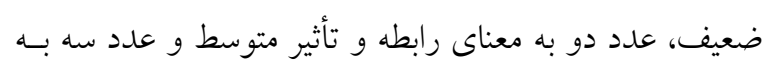

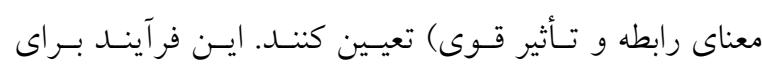
هركدام از دوازده روند جارى در بافـت تـاريخى شـهر تبريـز

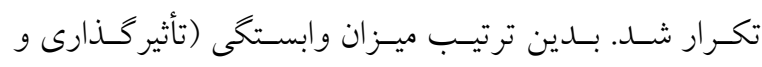

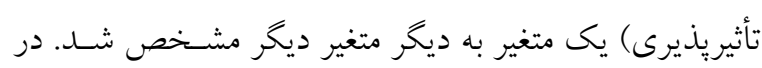

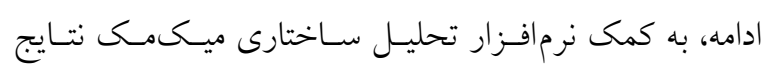
تحليل محاسبه شد. مـاتريس تشـكيلشـــه بــر اســاس اطلاعــات وارده در

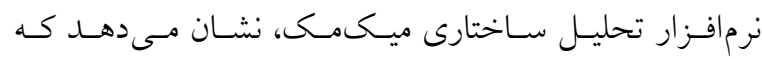

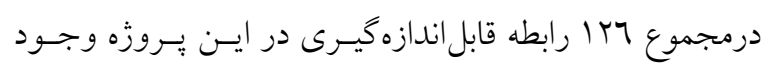

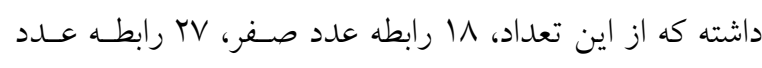
يك، سع رابطه عدد دو و 07 رابطه عـدد سـه بـوده اسـت. از
دانست. در اين يزوهش، به بررسى تأثير كلانروندها بر بستر

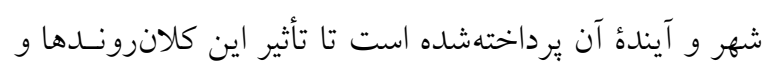

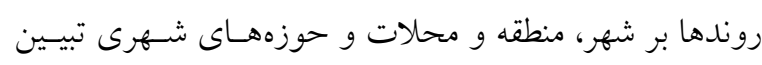

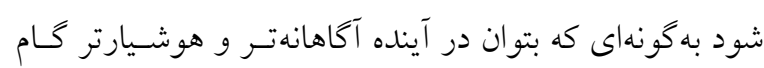
برداشت.

\section{بحث و يافتههاى يزوهث}

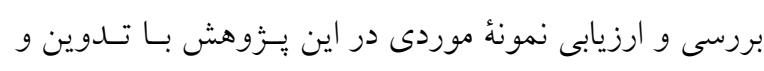

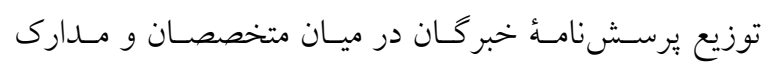

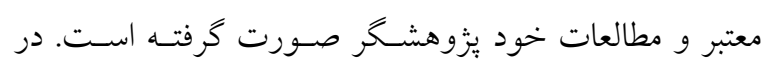
راستاى تدقيق روندهاى جارى در بافت تاريخى شـهر تبريـز، ابتدا يك يرسشنامهٔ مجزا براى دهَ نفر از متخصصان ارسـال و

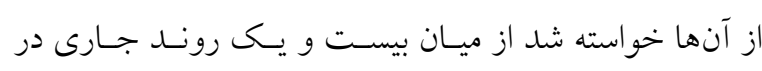
شهرهاى معاصر ايرانى، مهم ترين و تأثير گذارترين رونسدها را در شهر تبريز خاصه در بافت تاريخى انتخاب كنند و به آنهـا تريا

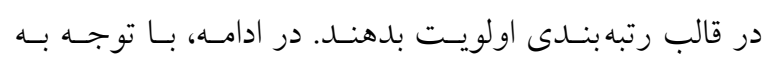
يرسشنامه هاى جواب دادهشده، اولويتهاى روندهاى جارى

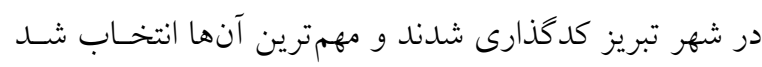
كه از ميان بيست و يـك رونـــ جـارى در شـهرهاى معاصـر

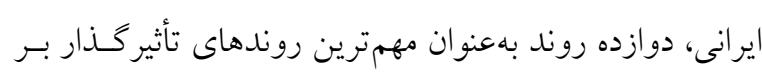

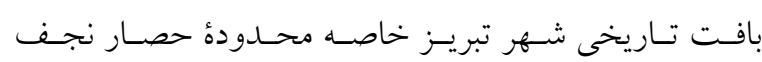
قلى خانى انتخاب شدند. اين دوازده روند انتخابى شامل: روند

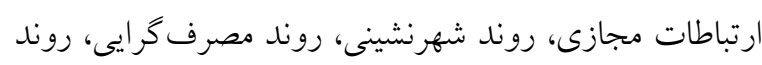

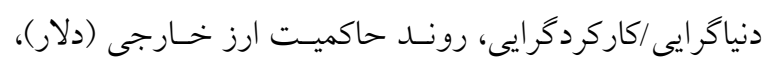
روند آيارتمان نشينى، روند تكنولوزى ساختمانى، روند قوانين رونين

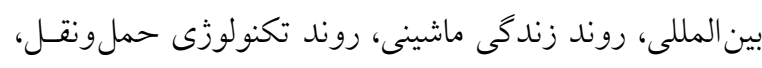

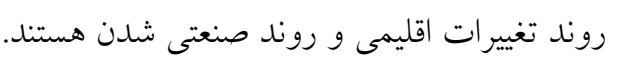

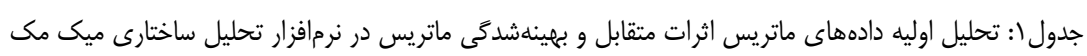

Table 1: Preliminary analysis of interaction matrix data and matrix optimization in Mic Mac structural analysis software

\begin{tabular}{|c|c|c|c|c|c|c|c|c|}
\hline درجه يرشدگى & جمع & تعداد سه & تعداد دو & تعداد يك & تعداد صفر & تعداد تكرار & ابعاد ماتريس & شاخص \\
\hline$\% \wedge \vee, \Delta$ & ITE & $\Delta S$ & Tr & TV & 11 & $r$ & IT & مقدار \\
\hline \multicolumn{3}{|c|}{ تأثيريذيرى } & \multicolumn{3}{|c|}{ تأثير گذارى } & \multicolumn{3}{|c|}{ هرخش } \\
\hline \multicolumn{3}{|c|}{$\%$} & \multicolumn{3}{|c|}{$\% 1}$. & \multicolumn{3}{|c|}{ קֶرخش اول } \\
\hline \multicolumn{3}{|c|}{$\% 1}$. & \multicolumn{3}{|c|}{$\% 1 \ldots$} & \multicolumn{3}{|c|}{ קرخش دوم } \\
\hline
\end{tabular}


واكاوى تأثيرات كلانروندها بر آيندة شهر ايرانى-اسلامى با رويكرد تحليل ساختارى و سناريونكارى؛

نمونهٔ موردى بافت تاريخى تبريز

جدول ז: توصيف عددى ميزان تأثير كذارى و تأثيريذيرى مستقيم و غيرمستقيم روندهاى بافت تاريخى تبريز بر اساس خروجى نرمافزار تحليل ساختارى ميك مك of Table 2: Numerical description of the impact and direct and indirect influence of the trends of the historical context of Tabriz based on the output of Mic Mac structural analysis software.

\begin{tabular}{|c|c|c|c|c|c|c|}
\hline \multicolumn{3}{|c|}{ اثرات غيرمستقيم } & \multicolumn{3}{|c|}{ اثرات مستقيم } & \multirow{2}{*}{ روندهاى جارى در بافت تاريخى شهر } \\
\hline رتبه & ميزان تأثيريذيرى & ميزان تأثير كذارى & رتبه & ميزان تأثيريذيرى & ميزان تأثير كذارى & \\
\hline 1. & 1.9rr & $14 \cdot 49$ & r & 19 & TQ & روند ارتباطات مجازى \\
\hline 1 & larr. & $I V \cdot V T$ & 1 & TV & r & روند مسائل شهرنشينى \\
\hline r & IFEMF & IQVQ. & r & e & rs & روند مصرفگرايى \\
\hline$\wedge$ & IrISV & ImAN & 8 & זr & זr & روند دنياكر ايى/كاركردمرايى \\
\hline 11 & qurs & $\| \varepsilon \wedge$. & 9 & 11 & rI & روند حاكميت ارز خارجى (دلار) \\
\hline r & IDIIV & IfFIT & $\Delta$ & re & ra & روند آيارتماننشينى \\
\hline$\Delta$ & IFAEV & 11198 & 11 & ع & 19 & روند تكنولوزى ساختمانى \\
\hline ir & quer & ( ) & ir & IV & 10 & روند قوانين بين المللى \\
\hline r & |QTYI & IETr. & r & tr & rq & روند زندگى ماشينى \\
\hline v & Imris & ITVET & $\wedge$ & re & tr & روند تكنولوزى حملونقل \\
\hline 9 & 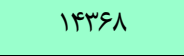 & IIETE & 1. & rQ & $r \cdot$ & روند تغييرات اقليمى \\
\hline 9 & פשrזו & IrDSq & $\checkmark$ & זr & זי & روند صنعتى شدن \\
\hline
\end{tabular}

دووجهى تعلـق دارد كـه درواقـع بسـيار تأثير كــار و بسـيار

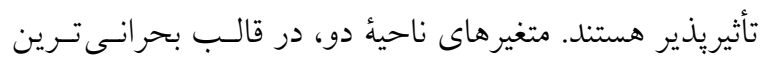

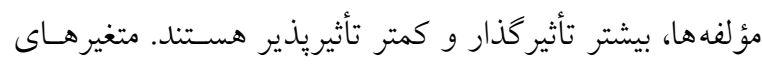

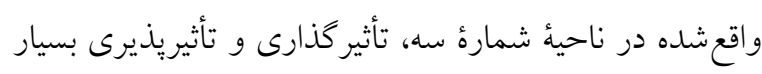

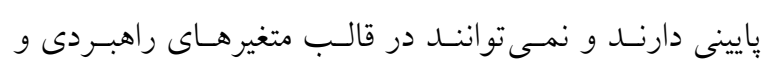

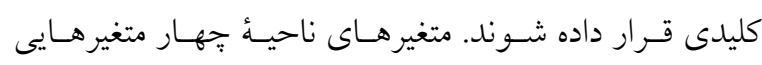

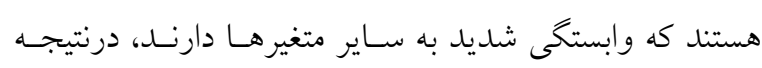
نمىتوان عنوان راهبردى را به آنها وارد دانست.

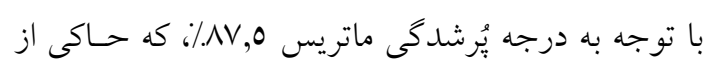

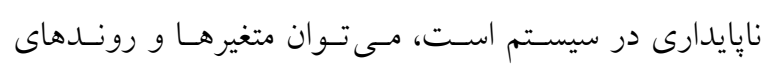

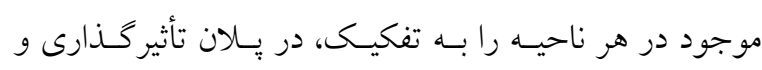

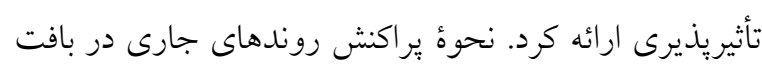

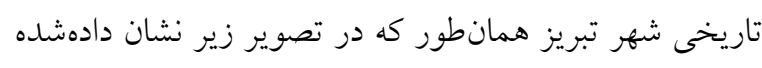

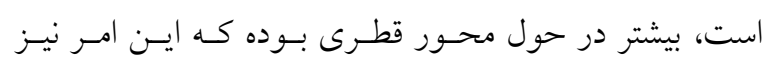

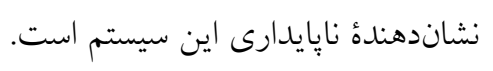

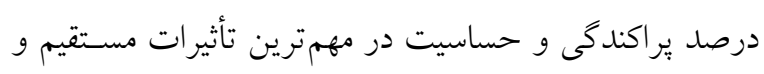

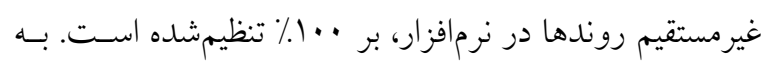

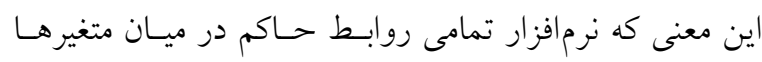

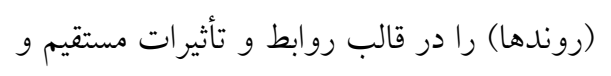

طرف ديخر ماتريس بر اساس شاخصهاى آمـارى بـا دو بـار

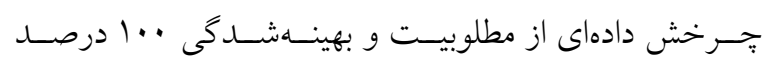

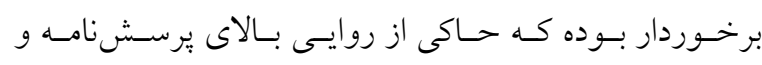

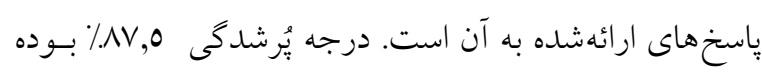

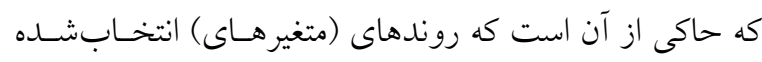

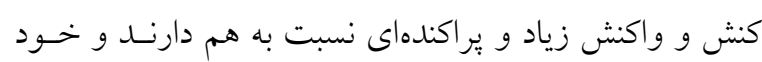
سيستم از شرايط نايايدارى برخوردار است.

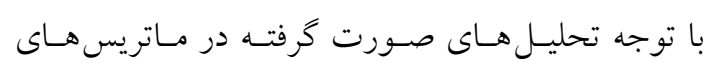

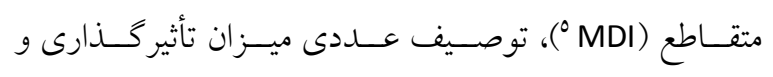

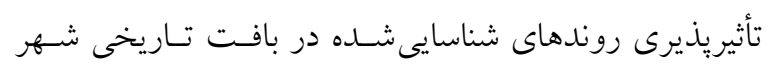

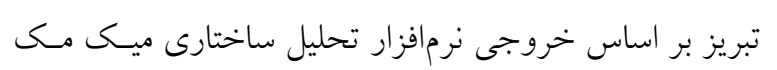
به شرح جدول ب است.

از مهمترين اصول در سـناريونخـارى، شناسـيى جايخـاه

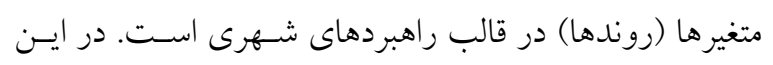

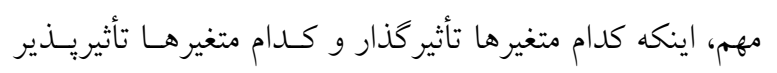
هستند، به تفكيك تبيين مسى شـوند. در ايسن راسـتا از نمـودار

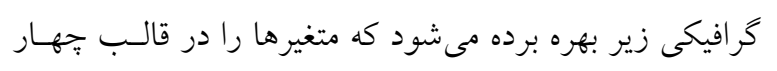
ناحيه بررسى مى كند. ناحيةُ شماره يكى به متغيرهاى (رونــدهاى) راهبـردى يـا 
روابط و تـأثيرات غيرمسـتقيم بـهـهـورت مجـزا، بـر اسـاس نظريات خبر كان و ماتريسهاى تشكيل شده، ارائه مىدهـد. در شكل زير نيز روابط مستقيم در ميان روندهاى جارى در بافت تاريخى شهر تبريز آورده شده است. خلاصـهُ تمــام تحليـل هــاى سـاختارى اتــرات متقابـل روندهاى جارى در بافت تاريخى شهر تبريز را كه بـر اسـاس نرمافزار تحليل ساختارى ميك مك ارزيابىشده، بدينصورت مى توان نمايش داد. همانطور كه در بررسىهاى نرم|فـزار تحليـل سـاختارى ميكمك نيز مشخص شد از مجموع دوازده رونسـ جـارى در

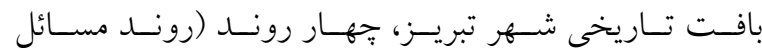

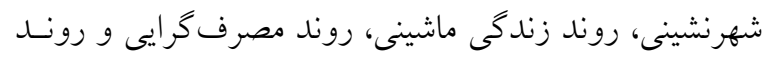

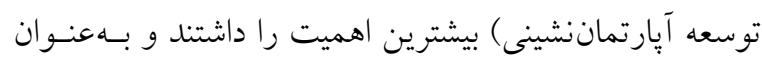
عامل كليدى بيشران، شناسايى شدند كه وضعيت هاى مختلف اين روندها درواقع شاكلة اصلى در تدوين ســاريوهاى آينـده

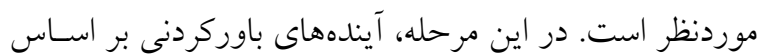
عوامـل راهبـردى و كليـدى شناسـايىشـــه در سـه ســاريو: سناريوى اول خوشبينانه و طلايى، سـناريوى دوم بدبينانسه و فاجعها آميز و سناريوى سوم ادامــهُ وضـع موجـود و محتمـل،

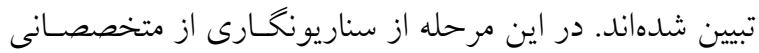

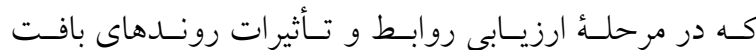
تاريخى شهر تبريز مشاركت داشتهاند، از ينج نفر، درخواسـت

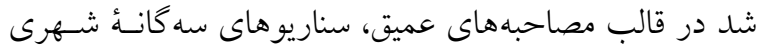
خود را با توجه به نتايج بهدستآملده از نرمافزار ميكمكى و

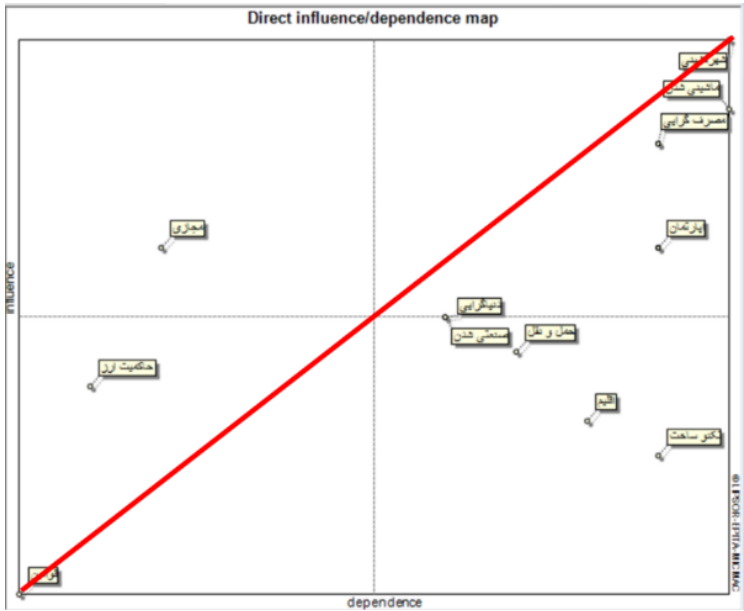

تصوير سّ: براكنش روندهاى جارى در بافت تاريخى شهر تبريز در پِان تأثير كذارى و تأثيريذيرى دافي تارئ

Fig. 3: Distribution of current trends in the historical context of the city of Tabriz in terms of impact and effectiveness

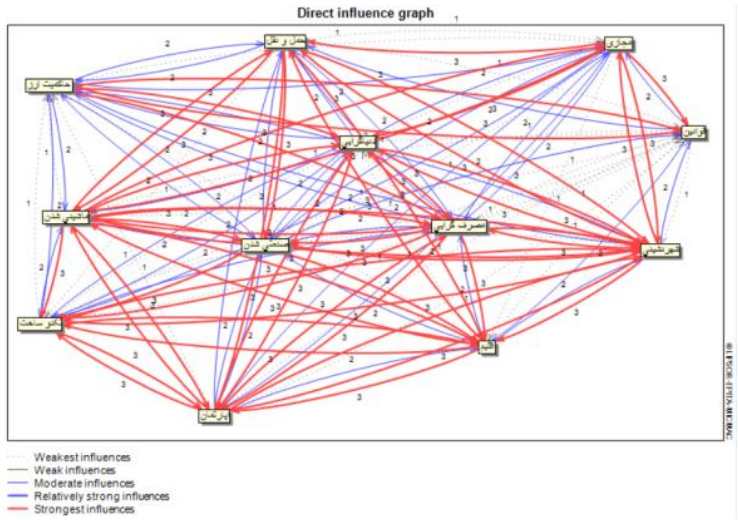

تصوير f: روابط و تأثيرات مستقيم در ميان روندهاى بافت تاريخى شهر تبريز Fig. 4: Relationships and direct influences between the trends of the historical context of Tabriz

جدول": موقعيت روندهاى بافت تاريخى شهر تبريز به تفكيك نواحى مختصاتى در تحليل ساختارى

Table 3: The position of trends in the historical context of Tabriz by coordinate areas in structural analysis

\begin{tabular}{|c|c|c|}
\hline \multicolumn{2}{|c|}{ وندها } & متغير/نواحى \\
\hline 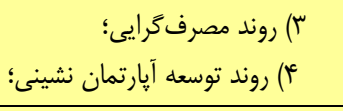 & () () روند مسائل شهرنشينى؛ & 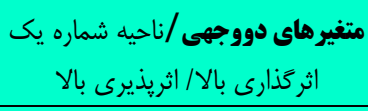 \\
\hline & ه) روند ارتباطات مجازى؛ & متغير هاى تأثير كذار/ناحيه شماره دو \\
\hline V روند قوانين بين المللى؛ & ع) روند حاكميت ارز خارجى (دلار)؛ & متغيرهاى مستقل/ناحيه شماره سه \\
\hline r) & ^) ^) روند دنياكرايى /كاركردگرايى؛ & 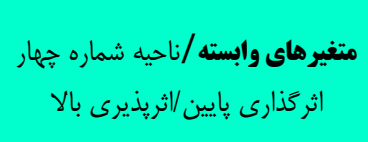 \\
\hline
\end{tabular}


واكاوى تأثيرات كلانروندها بر آيندة شهر ايرانى-اسلامى با رويكرد تحليل ساختارى و سناريونغارى؛ نمونهٔ موردى بافت تاريخى تبريز

موجود در بافت تاريخى كه ناشى از كترل حملونقـل بـوده،

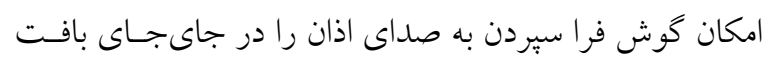

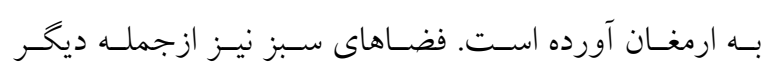

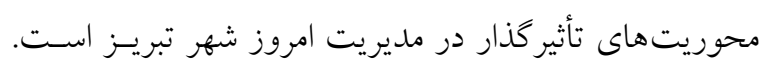

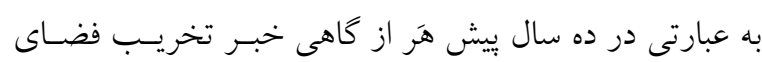

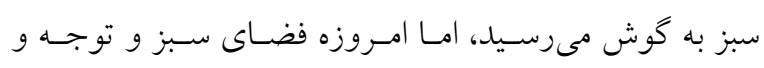

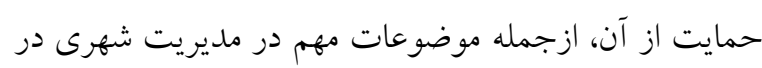
بافت تاريخى شهر تبريز است.

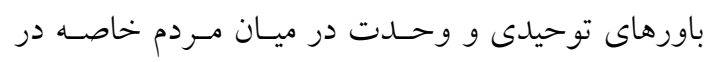

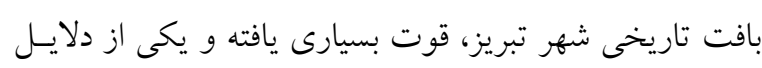

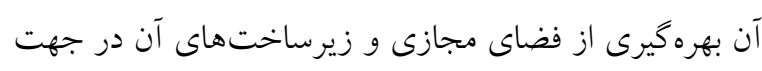

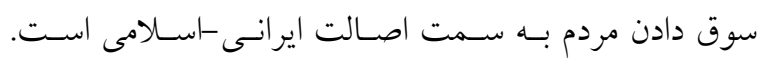

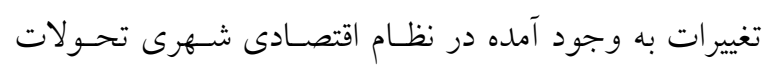

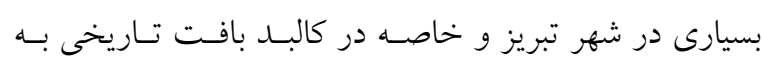

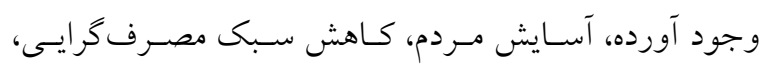

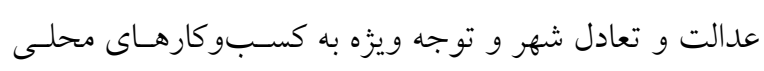

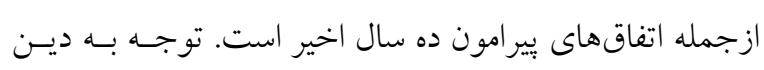

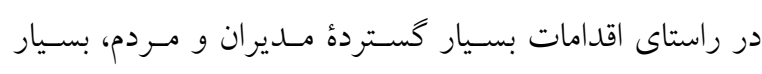
بيشتر از كذشته شده و در هر گامى كه در بافت تاريخى شهر

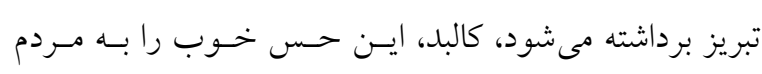
متتقل مى كند. توجه به سنت هاى ييشين ايرانى -اسلامى نظيـر

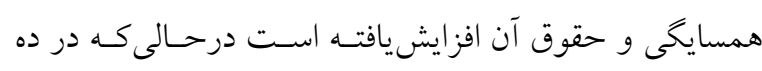

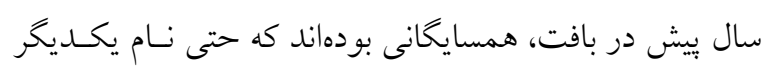

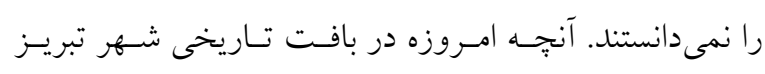

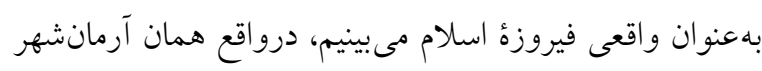

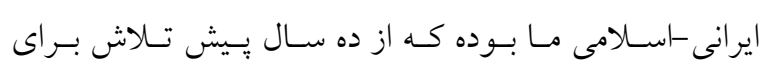

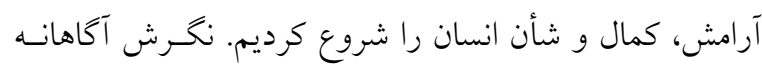

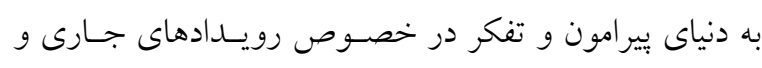

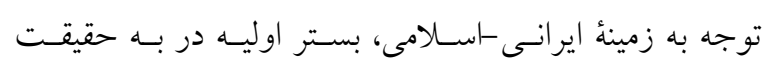
بيوستن بافت تاريخى تبريز امروز بود.

\section{سناريوى دوم (بدبينانه و فاجعهآميز)}

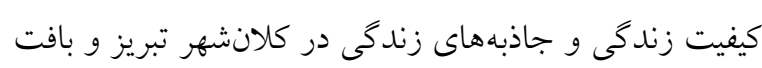

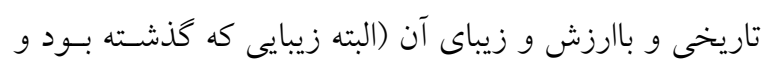

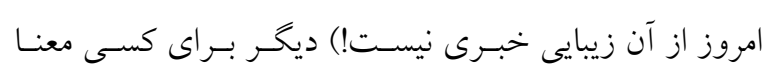

جنس متغيرهاى (روندهاى) موجود، ارائه كنند. بـا توجـهـ بـهـ مصاحبههاى انجامشده و تحليل هاى بهدست آمده، سناريوهاى (روناي

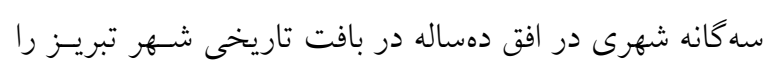
مىتوان به شرح زير ارائه كرد:

\section{سناريوى اول (خوشبينانه و طلايى)}

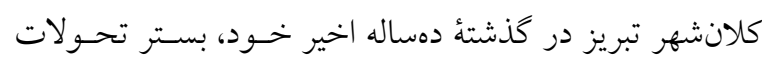

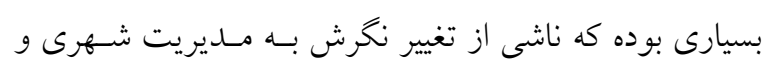

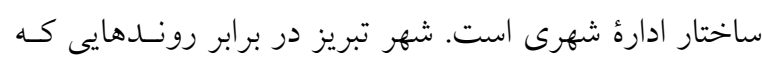

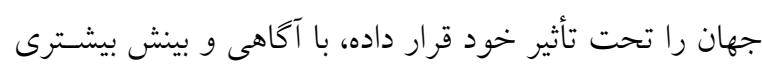

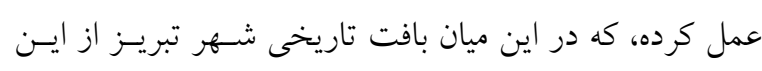

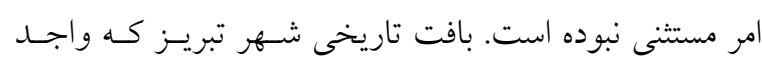
ارزشهاى بسيارى است در خصوص مسائل شهرنشينى، آثـار

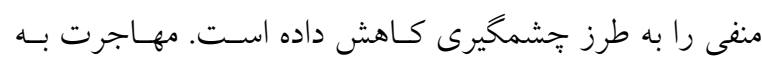

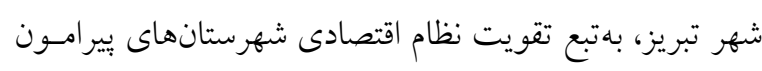

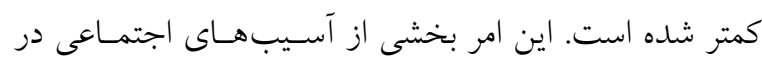

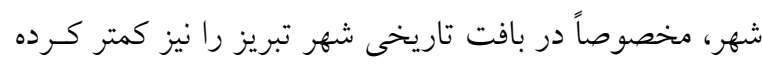

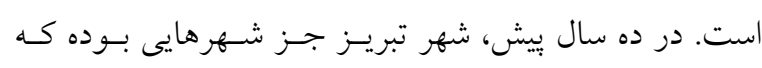

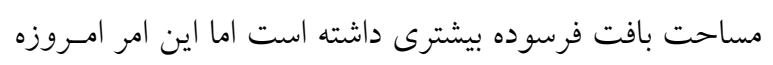

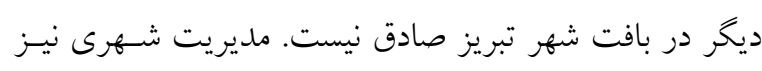

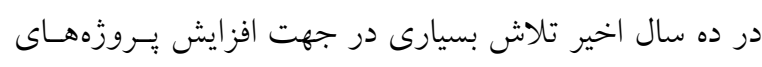

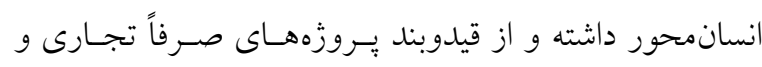

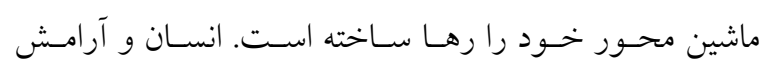

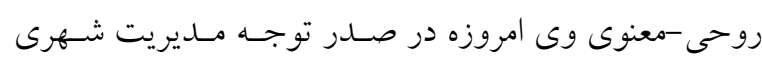

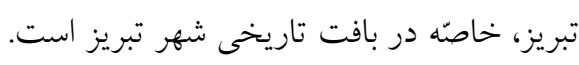

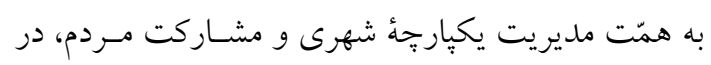

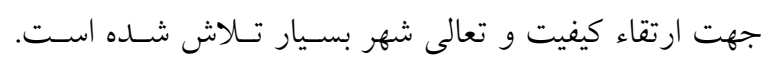

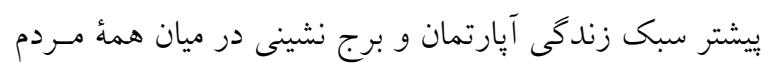

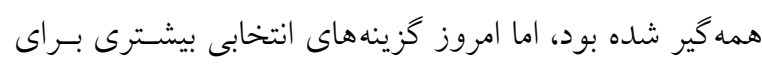

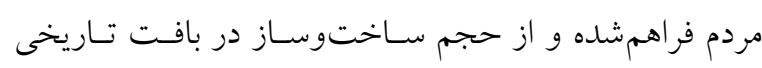

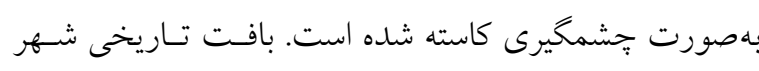

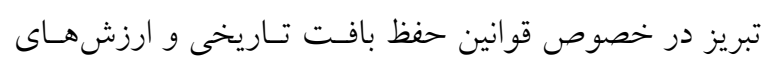

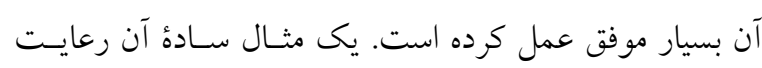

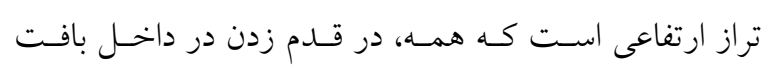

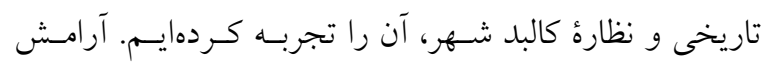




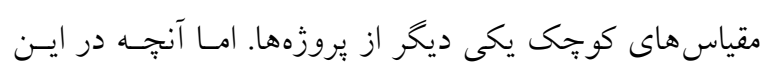

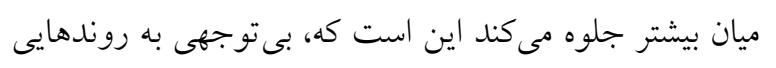

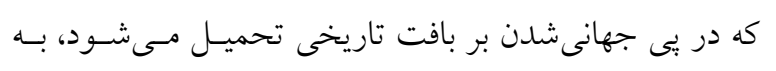

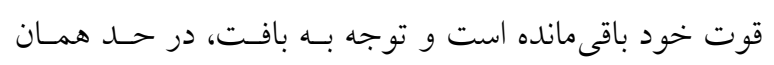

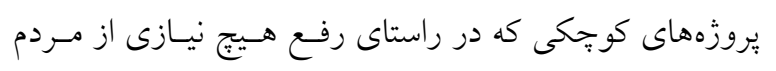

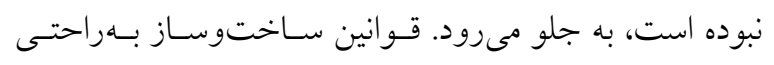

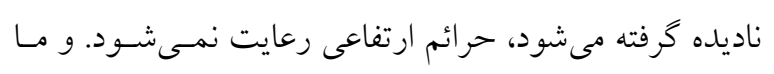

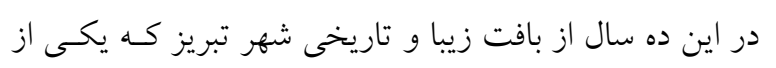

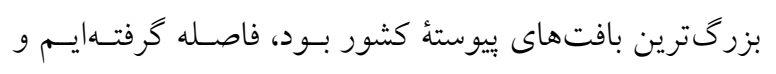

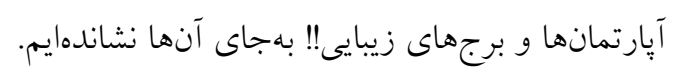

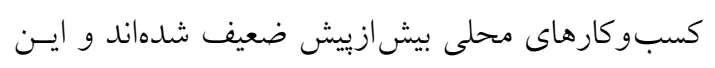

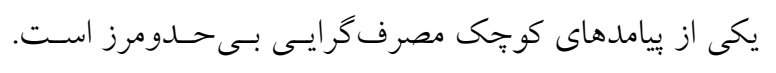

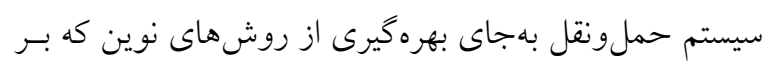

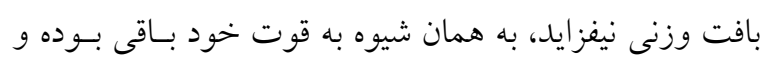

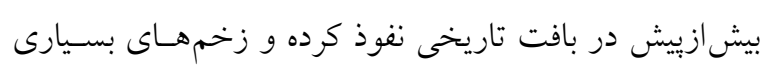

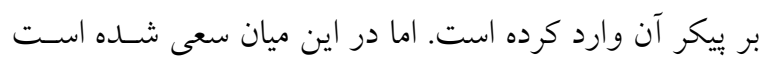

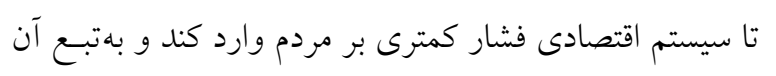

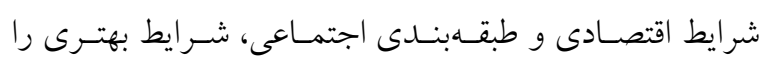

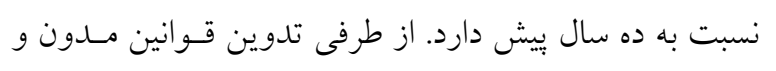

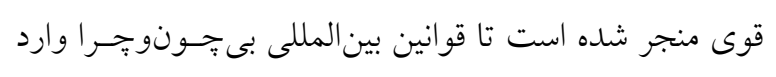

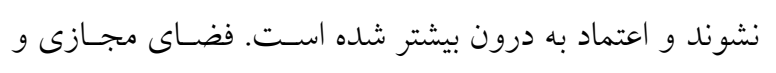

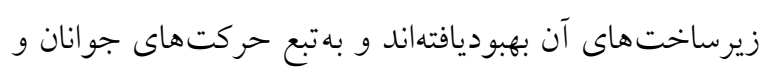

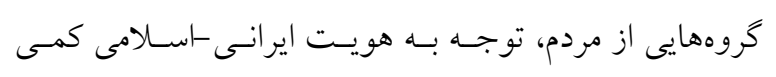

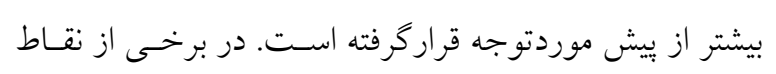

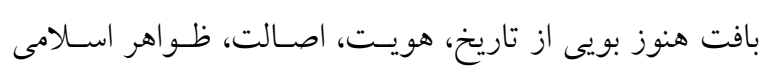

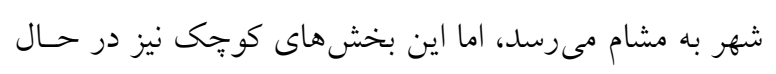

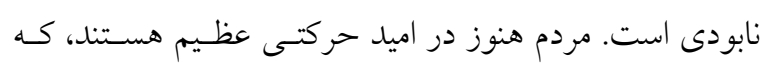

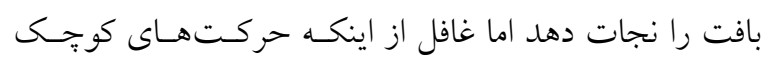

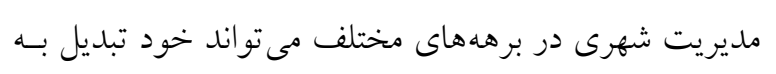

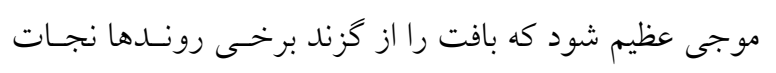

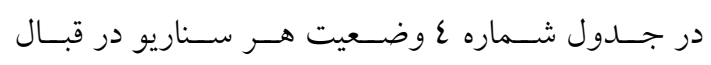
روندهاى دوازده كانه بافت تاريخى شهر تبريز به تفكيك نشان دادهشه است.
ندارد. زيرساختهاى فناورى و شهرى در كيفيت بسيار بايين

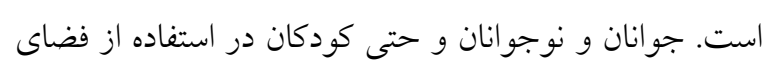

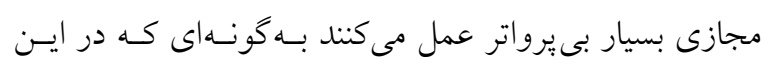

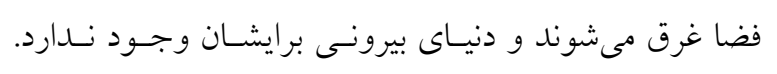

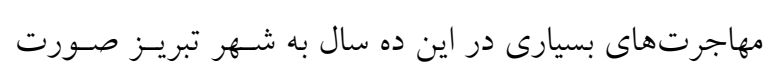

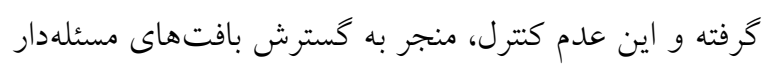
شهرى شده است. بافت تاريخى، مركز جولان برجسازان شده و ديخر اثـرى أنان

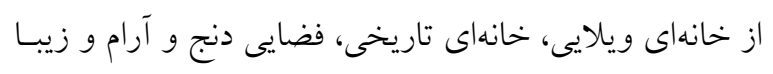

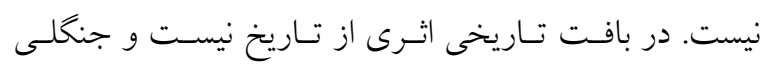

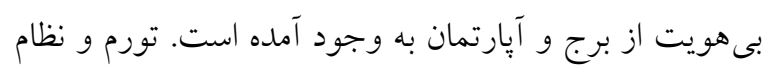

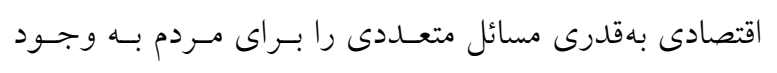

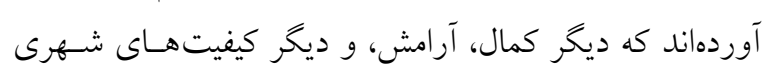

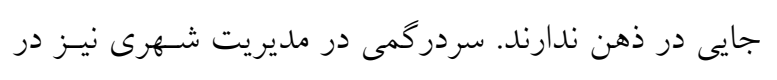

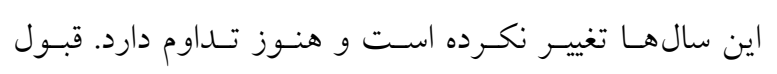

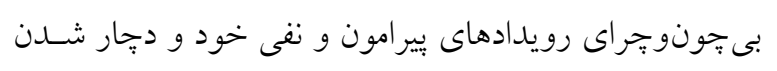

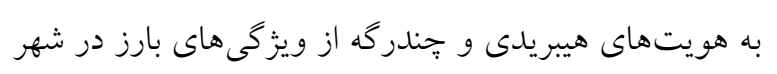

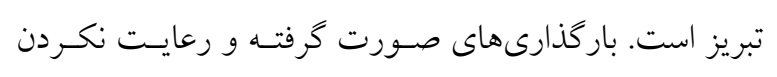

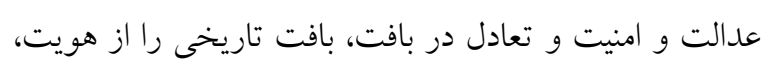
اصالت و ارزش هاى خود بسيار دور كرده، به كونهاى كه عملاً جيزى از كذشته در ذهن كسى نمانده است. از مفاهيم غريـب ارتب

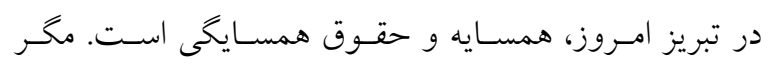

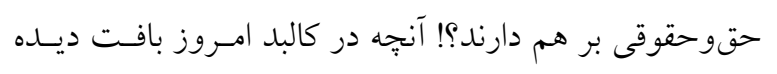

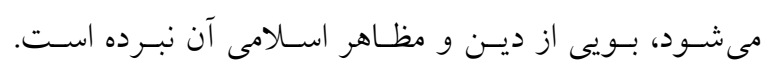

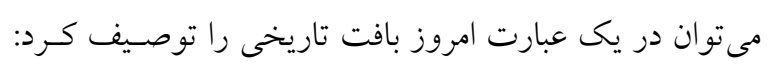
تسليم، بى :جونو:جرا!

\section{سناريوى سوم (ادامهٔ وضع موجود و محتمل)}

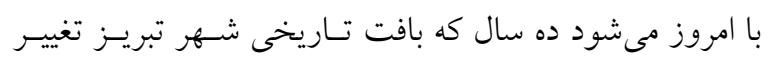

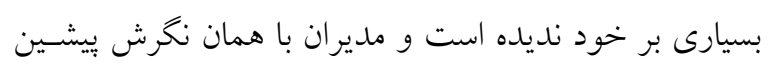

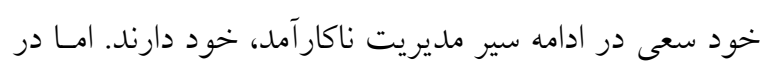

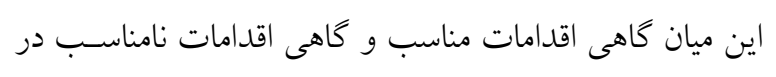

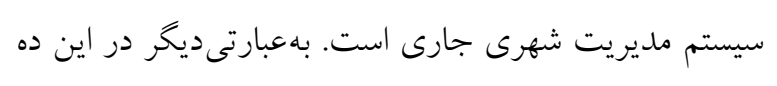

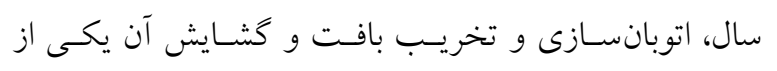

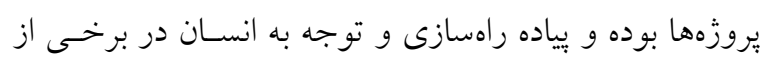


واكاوى تأثيرات كلانروندها بر آيندة شهر ايرانى-اسلامى با رويكرد تحليل ساختارى و سناريونگارى؛ تاري

نمونهُ موردى بافت تاريخى تبريز سناري

جدول ث: بررسى و ارزيابى تأثير روندها بر آينده شهر ايرانى -اسلامى در سناريوهاى سهكانه شهرى

Table 4: Investigating and evaluating the impact of trends on the future of the Iranian-Islamic city in the triple urban scenarios

\begin{tabular}{|c|c|c|c|}
\hline 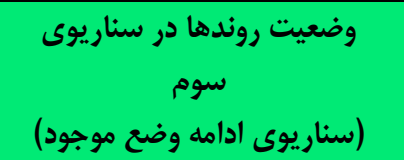 & (سناريوى بدبينانه و فاجعهآ وضآميز) & (سناريوى خوشت روندها در سناريوى اوله و طلايى) & روندهاى بافت تاريخى \\
\hline 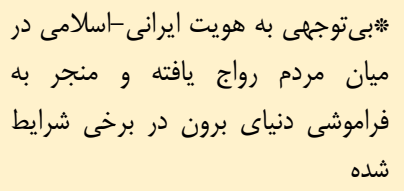 & 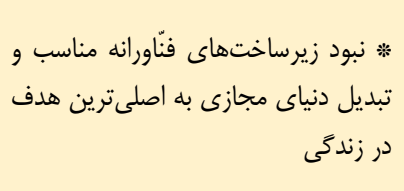 & جهت ارتقاى هويت ايرانى -اسلامى بافنوان يكىار در & روند ارتباطات مجازى \\
\hline 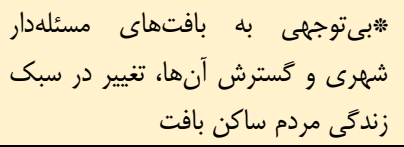 & 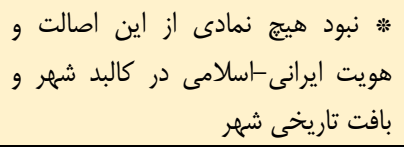 & براى تعالى كيفيت و مبدل شدن به بسترى & شير رونش مسائل \\
\hline 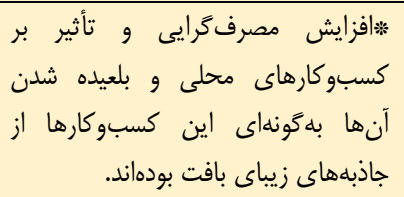 & 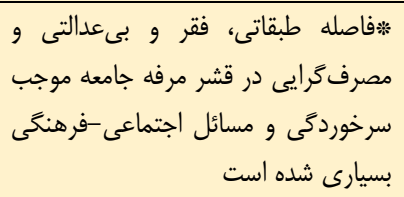 & * كاهش مصرفكرايى & روند مصرفترايى \\
\hline خود، ختوجهى به ساير همنوعان و توجه به & 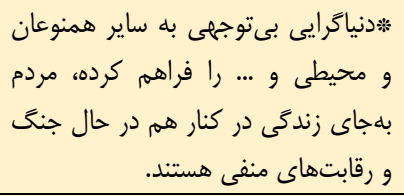 & اصالت ايرانى -اسلامى و همدلى به دنيا در جهت ارتقا & دنياتر ايى/كار كردترايى روند \\
\hline بافت بأثير بر سيستم اقتصاد و بهتبع آن در & نبود امنيت و تعادل در شهر و اق... & تقويت اقتصاد داخلى قدونين مدون و قوى در جهت & روند حاكميت ارز \\
\hline 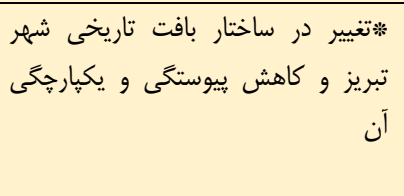 & 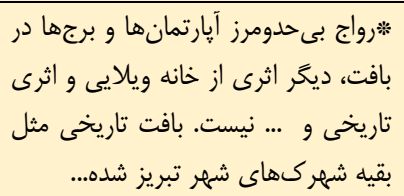 & 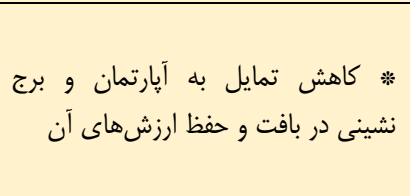 & \\
\hline 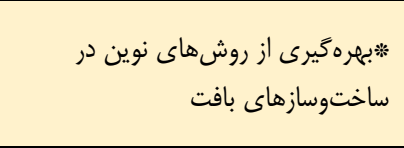 & بقى نبفيت زير نارضايتى هميشكى استفاده از روشه مردى & 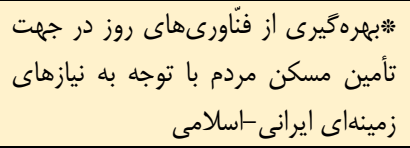 & روند تكنولوزى \\
\hline كنترلشده & 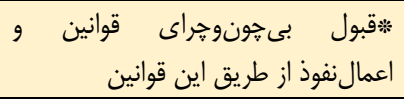 & تقويت سيستم شهرى قدانين مدون و قوى در جهت & روند قوانين بين المللى \\
\hline 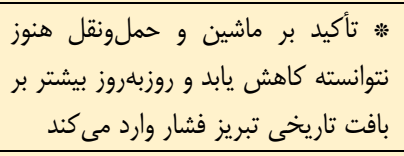 & 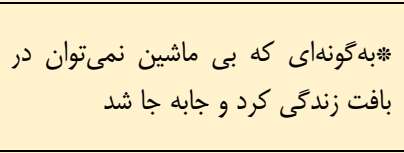 & 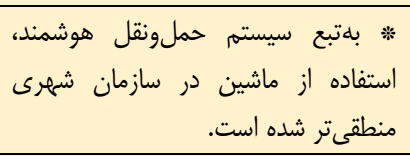 & روند زندكَى ماشينى \\
\hline 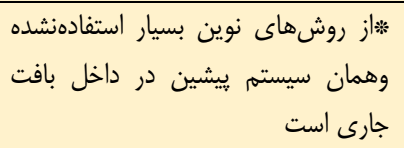 & و و وسايل بـى نيفيت و نارضايتى هميشكى و استفاده از سيستها & كيفيت بافت تاريخى و حفئه حفل هونقل هوشمند و ارتقا & روند فنّاورىهاى \\
\hline كردن آب و كوه و وخاكى ادامه دارد. & 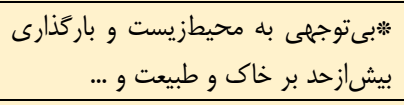 & 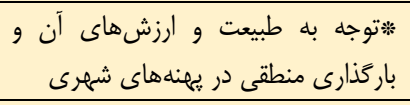 & روند تغييرات اقليمى \\
\hline داخل بافت و زندكى مصرفرايى، صنعتى شدن دارى است. & *تمايل بر آن روزبهروز افزايش مىيابد & 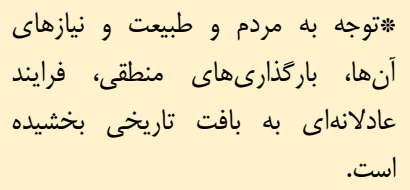 & روند صنعتى شدن \\
\hline
\end{tabular}




\section{نتيجلكَيرى}

بافت تاريخى شهر تبريز را مجدداً تأكيـــ مسىكنــ. از ميـان

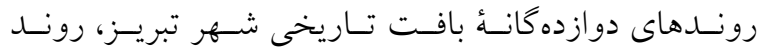

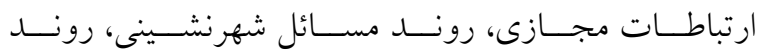
مصرف گرايى، روند زندگى ماشينى و روند آيارتمانششينى، بيشترين كرايش را به سمت سناريوى بدبينانه دارند. اين امر

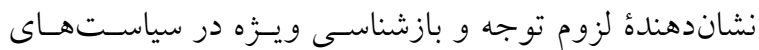
اركانها و نهادهاى مرتبط با روندهاى مذكور است.

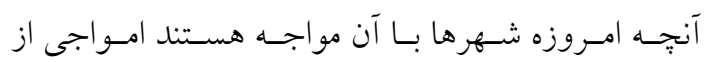
جهانىشدن است كه نياز به بهروزرسـانى را در تمـام سطوح شهرى مى طلبد. بى توجهى بـه ايـن موضـوع و يافشـارى بـر

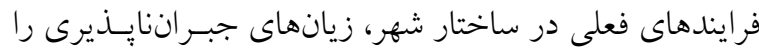

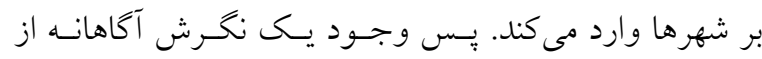

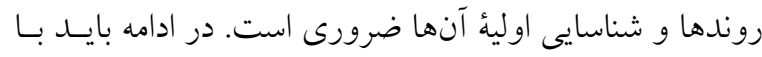

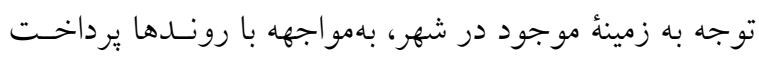

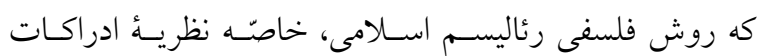

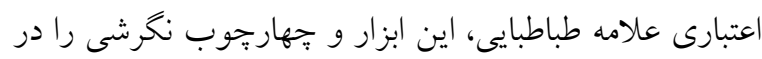

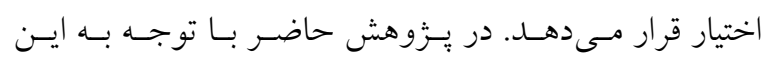

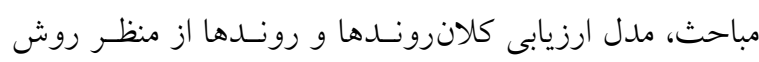

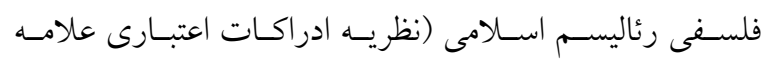

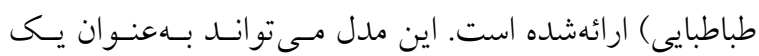

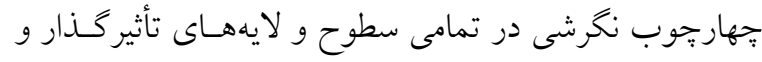

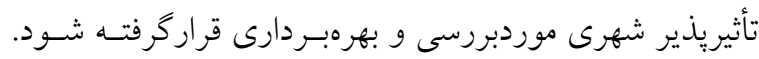

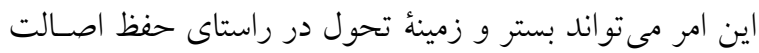
و هويت شهر ايرانى -اسلامى در دل بافتها شود و انشـاء الله در سطوح شهرى و شهروندى تأثير كذارد.

1. Megatrends

2. John Naisbitt

3. Patrick Dixon

4. MIC MAC_en_app

5. Matrix of Direct Influences
شهرها بهعنوان مهم تـرين دسـتاورد تـلاش هـاى اقتصـادى، فرهنكى و اجتماعى انسان مطرح مىشوند. بهعبـارتى ديخـر، شهر، غنى ترين مكانى است كه در گسـترهاش مسىتـوان بـهـ نشانهها و موجوديتهايى دستيافت كه محتواى تجربههاى

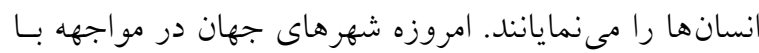

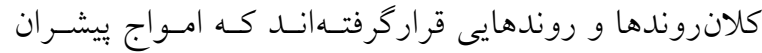

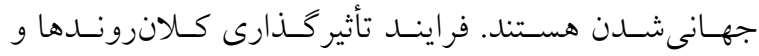
تأثيريذيرى شهرهاى ايرانى -اسلامى، موجب تضعيف و و بـهـ

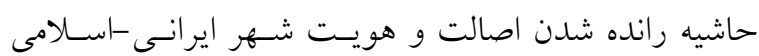
شده است و به عبارتى شهرها را بهسوى آيندهاى مبهم سوق مى دهد. ازاينروى، توجه به آينده ازجمله مهمترين اقدامات

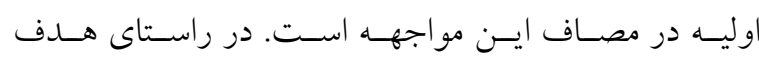
يثزوهش حاضر، بيست و يكى روند جارى در شـهر معاصـر

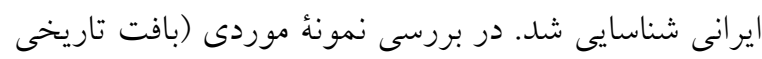

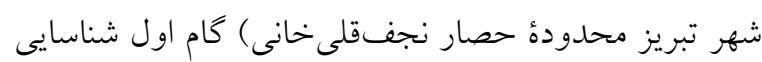
روندهاى جارى در خود شهر تبريز، خاصـه بافـت تـاريخى

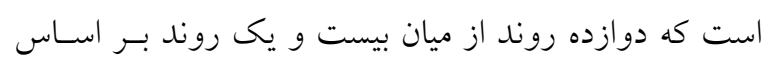

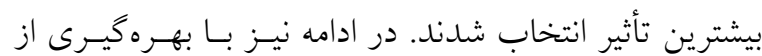
تكنيك ساختارى، جنس روندهاى شهر تبريـز تبيـين شـــ و سناريوهاى سه گانه شهرى در قالب سناريوى خوشبينانـه و طلايى، سناريوى بلدبينانه و فاجعهآميز و درنهايت سـناريوى

$$
\text { ادامله وضع موجود ارائه شد. }
$$

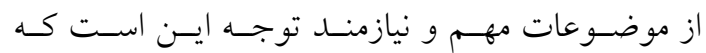

سناريوى سوم (سناريوى ادامه وضع موجود) جهت گيرى به

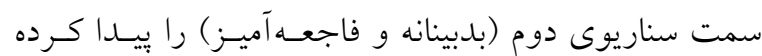
است كه اين موضوع نياز به بازنخرى جدّى در سياستهاى

يعنوشتها 
واكاوى تأثيرات كلانروندها بر آيندة شهر ايرانى-اسلامى با رويكرد تحليل ساختارى و سناريونگارى؛ تاري

نمونهُ موردى بافت تاريخى تبريز سناري

فهرست منابع

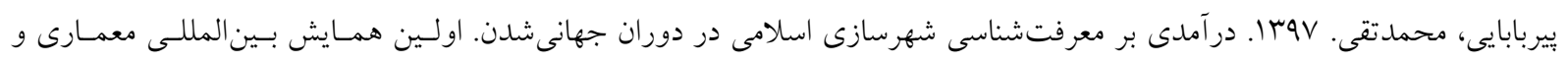

شهرسازى جهان اسلام در عصر جهانىشدن. دانشخاه هنر اسلامى تبريز. تبريز. بآس آبان ماه.

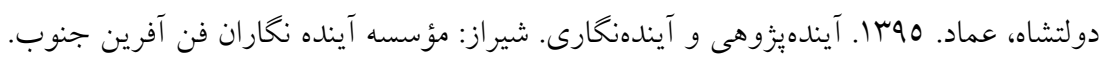

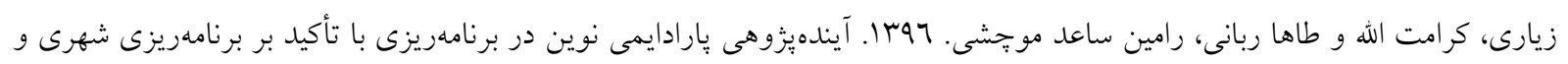

$$
\text { منطقهاى. تهران: انتشارات دانشخاه تهران. }
$$

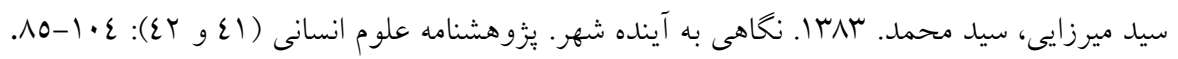

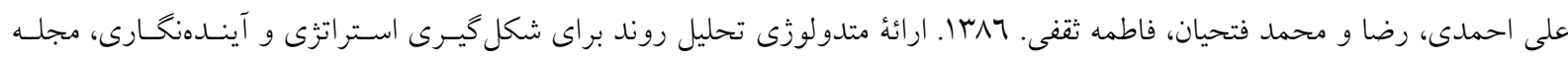

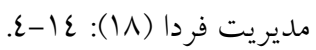

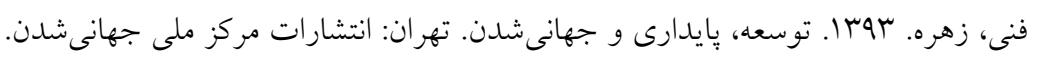

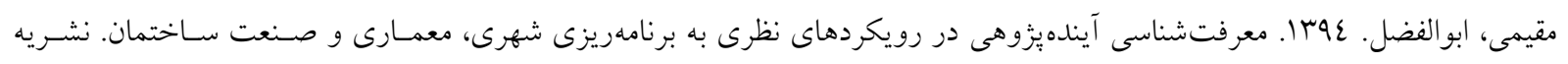

مديريت شهرى (rی)

نزادابر اهيمى، احد. سوبا. حصار نجف قلى خان و شكل گيرى و توسعةٌ تبريز در عهد قاجار. نشـريه بررسىهـاى نـوين تـاريخى (1) (1):

$$
.1 \cdot V-|r|
$$

Aliahmadi, Reza and Mohammad Fathian, Fatemeh Saghafi. 2007. Rovide process analysis methodology for strategy formation and foresight. Modiriat-e Farda Journal (18): 4-14. [In Persian]

Dixon, Patrick. 2016. The Future of (almost) everything. Kindle Edition.

Dollatshah, Emad. 2016. Futurology and futurism. Shiraz: Institute of Southern Futurists. [In Persian]

Fanni, Zohreh. 2014. Development, sustainability and globalization. Tehran: National Center for Globalization Publications. [In Persian]

Moqimi, Abolfazl. 2015. Future epistemology of theoretical approaches to urban planning, architecture and building industry. Journal of urban and rural management (38): 75-104. [In Persian]

Moller, Klaus-Johannes. 2012. A critical review of the megatrends and their implications for procurement. Master Thesis at University of Twente, School of Management and Governance. 1th supervisor: Prof. Dr. Holger Schiele. 2th supervisor: Niels Pulles.

Naisbitt, John. 1982. Megatrends: Ten New Direction Transforming Our Lives. New York: Warner Books.

NejadEbrahimi, Ahad. 2014. The fence of Najaf Gholi Khan and the formation and development of Tabriz in the Qajar era. Journal of Modern Historical Studies 1(1): 107-121. [In Persian]

Pirbabaei, Mohammadtaghi. 2018. An Introduction to the Epistemology of Islamic Urbanism in the Age of Globalization. The first international conference on architecture and urban planning of the Islamic world in the era of globalization. Tabriz Islamic art University. Tabriz. Nowember 14. [In Persian]

Schwenker, Burkhard, Tobias Raffel. 2014. THOUGHTS Megatrends. Roland Berger: school of strategy and economics.

Seyyedmirzaei, Seyyed Mohammad. 2014. A Look at the Future of the City. Journal of Humanities (41-42): 85-104. [In Persian]

Sheate, William, Tony Zamparutti, Suzan Bennetti, Melita Rogeli. 2007. EEA Research Foresight for Environmental and Sustainability (Final report). Collingwood Environmental Planning. Milieu Environmental Law \& policy.

Tan, Sor-hoon.2005. Challenging Citizenship: Group Membership and Cultural Identity in a Global age. Aldershot: Ashgate.

Toivonen, Marja. 2004. Expertise as Business (Long-term development and future prospects of knowledge-intensive business services (KIBS)). Helsinki University of technology, Laboratory of industrial management. Doctoral dissertation series.

Ziari, Keramatollah, Taha Rabbani, Ramin Saeed. 2017. Future research of a new paradigm in planning with emphasis on urban and regional planning. Tehran: University of Tehran Press. [In Persian]

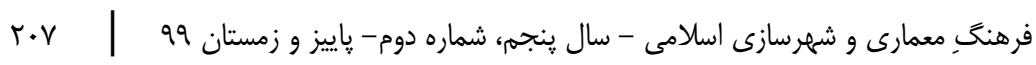

